\title{
Incidence and determinants of child labour in Nigeria: Implications for poverty alleviation
}

By

Benjamin Chiedozie Okpukpara

Centre for Rural Development and Cooperatives

University of Nigeria, Nsukka

and

Ngozi Odurukwe

Department of Agricultural Economics/Extension

Federal University of Technology, Owerri

AERC Research Paper 156

African Economic Research Consortium, Nairobi June 2006

THIS RESEARCH STUDY was supported by a grant from the African Economic 
Research Consortium. The findings, opinions and recommendations are those of the authors, however, and do not necessarily reflect the views of the Consortium, its individual members or the AERC Secretariat.

Published by: The African Economic Research Consortium

P.O. Box 62882 - City Square

Nairobi 00200, Kenya

Printed by: The Regal Press Kenya, Ltd.

P.O. Box 46166 - GPO

Nairobi 00100, Kenya

ISBN

9966-944-92-3

(C) 2006, African Economic Research Consortium. 


\section{Table of contents}

List of tables

Acknowledgements

Abstract

1. Introduction 1

2. Review of related literature 4

3. Results and discussion 6

4. Conclusion and policy implications 35

$\begin{array}{ll}\text { References } & 38\end{array}$

Appendix A Test of child activity options $\quad 41$

Appendix B Explanation of variable $\quad 41$ 


\section{List of tables}

1. Data on children aged between 5 and 14 years 3

2. Percentage distribution of child activities by gender of the child 7

3. Percentage distribution of child activities by zones in Nigeria 7

4. Percentage distribution of child activities in urban and rural Nigeria 9

5 Percentage distribution of child activity options in urban and rural Nigeria $\quad 10$

6. Activity status of children across gender and age, by per cent 10

7. Percentage distribution of children in different work activities 11

8. Percentage distribution of children in different work activities across zones 11

9. Percentage distribution of children according to their participation in different household chores

10. Activity status of children by parents' primary occupational status 13

11. Activity status of children by parental education 15

12 Activity status of children by presence status of parents in household 16

13. Households headed by children across gender and sectors 17

14. Percentage distribution of children according to their activity options with different household heads

15. Activity options of children and household size

16. Distribution of children according to age (years) of participation in work activities across zones, gender and sectors

17. Hours spent working in a week across ages and zones in Nigeria 20

18. Hours spent on part or full time work 21

19. Hours spent working in a week by category of children 21

20. Child activity options and household poverty status 22

21. Distribution of child labour activities across household income quintiles 23

22. Earnings of children across zones and activity options 23

23. Child earnings in naira across age groups 24

24. Child earnings per week across gender, categories and sectors in Nigeria, in naira 25

25. Amount contributed by children and its percentage of the household income 25

26. Stages of dropout of children 26

27. Reasons for never being in school 27

28. Percentage distribution of exclusive child labourers according to the time of the day worked

29. Percentage distribution of type of activities by exclusive child labourers across gender

30. Percentage distribution of children according to mode of payment 28

31. Benefit derived from employer by children in Nigeria by gender 28

32. Number of school days lost due to work 29

33. The logit regression results 31 


\section{Acknowledgements}

The authors are grateful to the African Economic Research Consortium (AERC), Nairobi, for their financial support. The authors also wish to thank the AERC resource persons for their useful and enriching comments as well as peers of the AERC biannual research workshop for the their invaluable comments and inputs on initial drafts of the study. The author s are grateful to members of the AERC network in general, and Group A thematic group (Poverty, Labour Market and Employment Issues) in particular. Finally, the authors are grateful to external reviewers of this paper for well-articulated comments and observations. Other apprciations go to the National Bureau of Statistics in Nigeria for providing the data used. However, the authors remain solely responsible for the views and shortcomings of the study. 


\section{Abstract}

Various official reports have established that child activity options have a link to household poverty. Specifically, research acknowledges a two-way link between child labour and household poverty. Some researchers argue that the increasing participation of children in economic activities is a result of illiteracy and poverty, among other social and economic problems. Others view such participation as an important strategy by poor households to rise above the poverty line. In Nigeria, reports have identified an increasing incidence of child labour, but comprehensive national analyses of the descriptive and causal factors of the child welfare variables - schooling and work - have not been possible until now. This study is therefore expected to fill this gap in knowledge using data from the Nigeria Child Labour Survey, 2001.

Among the major conclusions emerging from the study is that there are structural differences in the choice of child activity options across gender, age, sector and zones in Nigeria. Although the evidence of a sector gap exists, the participation of children in economic activity particularly increases in rural areas. In all the measures of poverty used, there are also differences in child activity options across poverty status, which points to poverty as an important variable of child welfare. Finally, there were percentage differences in income contribution across age groups, gender and zones in Nigeria. The econometric estimation noted that some child, parent, household and community variables significantly affect the child activity options. Specifically the age of the child, household composition, education of father, sector, zone and adult income determine child activity options. Most of these contradict or support many of the findings of child labour studies in other developing countries. Based on this it is recommended that for formulating effective policy to reduce child labour in Nigeria, the age of the child, income status of the household, education of the parents, and sector and zone must constitute important variables. Also, awareness campaigns on the cost of child participation in economic activities should be given priority. More importantly, if overall economic conditions are not improved to lift families out of poverty, children will continue to get involved in economic activities to enhance family income, irrespective of any regulatory or legislative prohibitions.

Key words: Child labour, poverty, Nigeria 


\section{Introduction}

7 he incidence of child labour is a widespread and growing phenomenon in developing countries, including Nigeria (Basu and Van, 1998). Genicot (1998) estimated the number of children engaged in the labour force as 250 million in developing countries. Labour force participation rates for children aged 5-14 years vary greatly from country to country, ranging from close to zero in most developed countries to an average of $20 \%$ in Latin America and $40 \%$ in Africa (Jayaraj and Subramanian, 1997; UNICEF, 2002).

The hazards associated with the involvement of children in the labour market are enough to hypothesize that child labour use persists in inverse relation to the degree of economic advancement of a society (Partrinos and Psacharopoulos, 1995). Yet, research conducted by Basu (1998) revealed that children contributed as much as one third of household income. The researchers concluded that children's income in poor families cannot be treated as insignificant in their poverty alleviation efforts. It has also been reported in some studies that such income helps the poor families to improve their welfare, thereby enabling them to send their children to school (Patrinos and Psacharopoulos, 1997).

The determinants of child activity options extend well beyond education to include the child's characteristics, parent's characteristics, household's characteristics and community characteristics. Knowledge of these determinants would inform a better child welfare management policy in Nigeria, but such analysis is lacking at the national level. In addition, within the empirical literature on child labour there has been a shift from mere quantification to econometric analysis of its determinants. This has coincided with a widespread realization that simply banning child labour is unlikely to eradicate the problem or may even make a household worse off.

The particular policy and research interest in this work is to ascertain the determinants of child labour, more especially in traditional African society where there is ineffective machinery to enforce child rights. In this context therefore, the paper seeks an in-depth knowledge of the incidence and determinants of child labour in Nigeria using data from the Child Labour Survey of 2001. This will offer policy makers and other agencies interested in child welfare and poverty reduction a good foundation for formulating appropriate policy. 


\section{Objectives of the study}

The broad objective of this study is to investigate the incidence and determinants of child labour in Nigeria as well as the implications of household poverty on the choice of child activity options. Specifically, the study seeks to:

- Identify different types of activity options in Nigeria.

- Examine the child activity options as patterned by child, parent and household variables, as well as location and zones.

- Examine the income from child participation in economic activities as patterned by location, gender and age of the child, as well as hours spent in different child labour activities.

- Measure the effects of child, parent, household and community characteristics on different child labour use decisions.

\section{Research hypotheses}

n the basis of the specific objectives of the study, the following null hypotheses were tested:

- There is no significant difference between the participation in child activity options in urban and rural Nigeria.

- There is no significant difference in child activity options across zones in Nigeria.

- There is no significant difference in child activity options across gender in Nigeria.

- Child characteristics, parent characteristics, household characteristics and community characteristics have no significant effect on child labour decisions by household.

\section{Justification for the study}

$\mathrm{T}$

here is wide disagreement on how to tackle the problem of child labour. This stems partly from lack of awareness of the causes of child labour, and problems associated with stopping child labour through legislation. This study is therefore expected to identify the major factors that influence child activity options in Nigeria. The general significance of this research is that the study will bring to light the determinants of child activity options as well as the link between child labour and poverty in Nigeria. This will help make policy on this issue for households and government to safeguard our children and promote their contribution to economic growth and development in Nigeria. The study will also be a reference point for further research on child activity options in Nigeria and other developing countries. 


\section{Research methodology}

This study used data from the survey conducted by the Federal Office 1 of Statistics (FOS) and the International Labour Organization (ILO) from July 2000 to February 2001 in Nigeria.

Specifically, the sample design was constructed to provide a robust estimate at the state level and Abuja (the capital of Nigeria). Therefore, in each state except the Federal Capital Territory (FCT) Abuja, a sample of 60 enumeration areas (EAS) comprising 30 urban and 30 rural were selected. Ten (10) housing units were selected in each EAS, thereby providing 600 housing units in each state except FCT, where 300 were targeted. This gave a proposed national sample size of 22,200 housing units. Of these, 21,900 households responded, among which are 32,354 children aged between 5 and 17 years of age. The actual data were collected from 20,830 household units, comprising 100,785 individuals, among whom are 32,354 children aged 5-17 years of age. After data cleaning, the numbers came to 20,416 households, 100,654 individuals and 32,245 children.

The actual data used in this analysis are shown in Table 1. Children aged between 5 and 14 years were selected to conform to the international definition of child.

\section{Table 1: Data on children aged between 5 and 14 years}

\begin{tabular}{lr}
\hline Details & Number \\
\hline Total number of individuals & 100,654 \\
Total number of children & 32,308 \\
Total number of children working only & 938 \\
Total number of children combining school and work & 6,712 \\
Total number of children schooling only & 14,136 \\
Total number of children participating in neither work nor school (idling ) & 1,059 \\
\hline
\end{tabular}

Note: Work in this study includes all economic activities engaged in by children, whether paid or unpaid except domestic chores (for example, waged work, work in family enterprise/farm, self-employment, apprenticeship whether paid or unpaid).

Source: Child Labour Survey, 2001. 


\section{Review of related literature}

hild labour use in developing countries is a fundamental social problem with
grave consequences for economic development. It is the participation of young
children under the age of 15 years in the labour force in order to earn a living or support household income (Grootaert and Kanbur, 1995). It has been reported that child labour could lead to mass dropout from primary and secondary schools (Canagarajah and Coulombe, 1997). Child labour is not only a growing phenomenon in the developing countries but is also assuming a different dimension. ILO (1996) estimates put the prevalence of child labour at 250 million in developing countries, out of which $61 \%$ is in Asia, 32\% in Africa and 7\% in Latin America. The same source indicates that 120 million children are full time workers and $80 \%$ are between the ages of 10 and 14 years. Basu (1998) reports that in terms of child labour force participation rates, Africa ranks highest, with 33\% in East Africa, 24\% in West Africa and 22\% in Central Africa. This phenomenon hampers human capital development and the potential of developing countries, as Ravallion and Wodom (2000) observe.

Inasmuch as many researchers have viewed child labour as an index of poverty, neediness, subsistence living and general deprivation, they have recommended outright abolition (Patrinos and Psacharopoulos, 1997).

Ray (2000) notes that the universal perception of child labour as a problem stems from the widespread belief that employment is destructive to children's intellectual and physical development, especially that of young children. The danger is particularly serious for children who work in hazardous industries. He observed that working prevents children from benefiting fully from school and may thereby condemn them to perpetual poverty and low wage employment.

Basu (1998), however, views child labour as a way out of poverty especially for poor households. Basu observes that children contribute as much as one-third of household income in poor families. He states that such income could not be treated as insignificant in poverty reduction in poor households. Notwithstanding, Nielsen (1998) does not find a positive relationship between poverty and child labour, and thus raises doubts about the claim of poverty being a main determinant of child labour (e.g., Grootaert and Kanbur, 1995). Canagarajah and Coulombe (1997) analysed 1991/92 data in Ghana and drew results similar to the Neilsen study. Per capita household income was used as a proxy for welfare or an "inverse" measure of poverty. The result showed a weakly inversely Ushaped relationship with child labour.

In addition, Ray (2000) notes that child labour need not necessarily be "bad", nor warrant action from policy makers. Indeed some (low, non human capital affecting) 
levels of child labour may even stimulate the children in their personal development as well as generate a natural attachment to the labour market at an early age. Thus, child labour can be beneficial, rather than harmful, as long as it is not undertaken at the expense of educational attainment.

The causes of child labour as reported in the literature are many. Bonnet (1993) reported that a debt incurred by the parents is often the bond that forces the child to work toward repayment of the debt. ILO (1992) confirms this, but notes that such bonds usually occurred in South Asia where there were several millions of legally child-bonded labourers especially in informal sectors. Rimmer (1992) noted that in most cases child labour is determined by the poverty status of the household and level of parental education. Psacharopoulos (1997) noted that if the parents have irregular employment, this creates the need for additional or more stable income sources to be provided by children. Studies by Lloyd and Blanc (1994) and Grootaert (1998) revealed that child, parent and household characteristics as well as school characteristics (i.e., expenditure in school and distance to the school) are important variables affecting whether children participate in economic activities. In addition, Siddiqi and Patrinos (1995) concluded that location could also be an important factor in child labour force participation. They observed that children in rural areas participate more in the labour market because of larger land holdings. This means that the tendency to engage in child labour increases with farm size. In addition, the literature on the determinants of school enrolment has also clearly established one effect, which is a substitution effect between the schooling of girls and the labour force participation of the mothers (Levison, 1991).

The review of literature confirmed two schools of thought. One view is that child labour is detrimental to the child, the household and even the country's human capital development. The other is that child labour is not necessarily harmful to the child provided that it is not undertaken at the expense of the child's schooling. In addition, a lot of controversy surrounds the links between child labour and poverty reported in empirical studies. More so, none of these works were done in Nigeria. With this recent survey conducted by the Federal Office of Statistics (FOS) in conjunction with ILO in Nigeria, we explore what determines different child activity options and how these are linked to poverty alleviation in Nigeria. 


\section{Results and discussion}

7 he descriptive results cover activity options, parent and household characteristics, and sectors and zones. Parent characteristics include employment, education, presence in the household and gender, while household characteristics include size and the numbers of adults and children. These finding are discussed in the following paragraphs.

\section{Children activity options in Nigeria}

Children spend their time in different activities in Nigeria, divided into work, school and leisure. These activities are broadly categorized internationally into work only, school and work, and school only. The data do not cover estimates from leisure. The result shows that participation in work and schooling activities differs across zones, gender and sectors in Nigeria.

Table 2 shows that although there is no clear association between schooling and age, there seems to be a high concentration of full-time schooling at earlier ages of the child. The table also shows that although fewer children are in full-time work activity (work only), there is a high cohort of these children aged 9 to 10 years as well as aged 12 to 14 years. A similar trend is observed among school children participating in economic activities (school and work). It is also evident from the table that there is a clear indication that as children grow older, their participation in economic activities increases.

Children who participate neither in school nor in economic activities are mostly aged between 5 and 6 years. This may be attributed to a delay in school enrolment among children in Nigeria. The table also shows that $93 \%$ of children are enrolled irrespective of their involvement in economic activities.

In terms of gender, the table shows that there is little or no gender gap between male and female children in participation across ages. Although there is no marked difference between male and female participation in full-time schooling, slightly more male children participate in full-time schooling than their female counterparts. The explanation of this observed trend might be the introduction of the universal basic education programme and the vigorous campaigns on the importance of girl-child education in Nigeria, which narrows the gender gap in participation in full-time schooling.

The table also shows that of the sampled children in Nigeria $27 \%$ of females and $25 \%$ of males combined school with some economic activities. Further analysis finds that participation of male children in full-time work is consistently higher than that of females at all ages. 
Table 2: Percentage distribution of child activities by gender of the child

\begin{tabular}{|c|c|c|c|c|c|c|c|c|c|c|c|c|}
\hline \multirow[t]{2}{*}{ Age } & \multicolumn{3}{|c|}{ School only } & \multicolumn{3}{|c|}{ Work only } & \multicolumn{3}{|c|}{ School and work } & \multicolumn{3}{|c|}{ Idle } \\
\hline & $\mathbf{M}$ & $\mathbf{F}$ & All & M & $\mathbf{F}$ & All & M & $\mathbf{F}$ & All & M & $\mathbf{F}$ & All \\
\hline 5 & 63 & 62 & 63 & 3 & 2 & 3 & 11 & 12 & 11 & 22 & 25 & 23 \\
\hline 6 & 72 & 67 & 69 & 3 & 2 & 3 & 17 & 21 & 19 & 8 & 10 & 9 \\
\hline 7 & 68 & 72 & 70 & 4 & 2 & 3 & 25 & 24 & 24 & 3 & 2 & 3 \\
\hline 8 & 70 & 67 & 69 & 3 & 2 & 3 & 25 & 28 & 27 & 1 & 3 & 2 \\
\hline 9 & 69 & 69 & 69 & 5 & 2 & 5 & 25 & 28 & 26 & 1 & 1 & 0 \\
\hline 10 & 64 & 64 & 64 & 5 & 3 & 5 & 30 & 32 & 30 & 1 & 1 & 1 \\
\hline 11 & 68 & 66 & 68 & 5 & 2 & 3 & 30 & 36 & 29 & 0 & 0 & 0 \\
\hline 12 & 64 & 65 & 64 & 4 & 3 & 4 & 31 & 32 & 31 & 0 & 0 & 1 \\
\hline 13 & 63 & 67 & 63 & 5 & 3 & 5 & 31 & 30 & 31 & 1 & 0 & 1 \\
\hline 14 & 65 & 64 & 65 & 5 & 4 & 5 & 29 & 31 & 30 & 0 & 1 & 0 \\
\hline All & 67 & 66 & 67 & 4 & 3 & 3 & 25 & 27 & 26 & 4 & 4 & 4 \\
\hline
\end{tabular}

Note: $\mathrm{M}=$ Male children; $\mathrm{F}=$ Female children.

Source: Child Labour Survey, 2001.

It is also evident from the table that participation in the work only category increases as the child gets older. The possible explanation for this is that participation in full-time work requires more energy, which is acquired when the child grows older.

There is also a marginal gender gap among the idling children (that is, neither in work nor in school) as well as those participating in full-time work, which narrows as the age of the child increases. This explains the fact that although a higher percentage of children may have been enrolled, most children in Nigeria are faced with delayed enrolment. Similar results have been found elsewhere (Glick and Sahn, 1997). More importantly, the test of differences between means shows that male participation in all child activity options is significantly different from female activity options except in the case of idling (see Appendix Table A1). Table 3 presents the distribution of child activity options across regions in Nigeria.

Table 3: Percentage distribution of child activities by zones in Nigeria

\begin{tabular}{|c|c|c|c|c|c|c|c|c|c|c|c|c|}
\hline \multirow[t]{2}{*}{ Zones } & \multicolumn{3}{|c|}{ School only } & \multicolumn{3}{|c|}{ Work only } & \multicolumn{3}{|c|}{ School and work } & \multicolumn{3}{|c|}{ Idle } \\
\hline & $\mathbf{M}$ & $\mathbf{F}$ & All & $\mathbf{M}$ & $\mathbf{F}$ & All & $\mathbf{M}$ & $\mathbf{F}$ & All & $\mathbf{M}$ & $\mathbf{F}$ & All \\
\hline 1. NC & 61 & 61 & 61 & 6 & 4 & 5 & 29 & 29 & 29 & 4 & 5 & 5 \\
\hline 2. NE & 46 & 50 & 48 & 17 & 13 & 15 & 28 & 28 & 28 & 9 & 9 & 9 \\
\hline 3. NW & 63 & 60 & 61 & 4 & 3 & 3 & 26 & 28 & 27 & 7 & 9 & 8 \\
\hline 4. SE & 65 & 62 & 64 & 0 & 0 & 0 & 34 & 38 & 36 & 0 & 1 & 0 \\
\hline 5. SS & 59 & 59 & 59 & 0 & 0 & 0 & 40 & 40 & 40 & 1 & 2 & 1 \\
\hline 6. SW & 93 & 90 & 92 & 1 & 0 & 1 & 6 & 8 & 7 & 1 & 2 & 1 \\
\hline
\end{tabular}

Note: $\quad$ Zone 1 = North Central; Zone 2 = North East; Zone $3=$ North West; Zone 4 = South East; Zone 5 = South South; Zone 6 = South West; $M=$ Male children $F=$ Female children.

Source: Child Labour Survey, 2001. 
The table shows that over $72 \%$ of children in Southern zones are in full-time schooling compared with less than 58\% in Northern Nigeria. Moreover, children from Southwest Nigeria had the highest participation in full-time schooling, representing $92 \%$ of total sampled children in that zone, while children from Northeast Nigeria had a relatively low school enrolment (48\%). This may be attributed to early adoption of Arabic education in Northern Nigeria and western education in Southern Nigeria, suggesting a differentiation along religious lines. The relatively high incidence of schooling children in Southwest Nigeria is expected because the zone is the former capital of Nigeria from where western education was first established and extended to other zones in Nigeria.

In terms of gender-specific activity options across zones, the table shows that over all the zones in Nigeria, male participation in full-time schooling dominates that of females except in North East Nigeria where there is a marginal difference in favour of female child education. Two things could be responsible for this. First, there may be less evidence of discrimination in the zone. Secondly and more importantly, nomadic influences may be more prominent in the zone, which favours the migration of male children to other zones. In addition, the relatively high incidence of males in full-time schooling is not a surprise because of the importance attached to the male-child in traditional African society. Overall, there is little or no evidence of discrimination against female children in school enrolment. This is supported in the literature. The fact that female children are more likely to combine schooling with economic activities may be an indication (although not conclusive) that female children work so that male children may be enrolled.

The table also shows that although there is equal participation of schooling children in economic activity, it is more likely that schooling female children will participate in economic activity in Northwest and Southeast Nigeria. The table also shows that there is higher percentage of children in full-time economic activities in the North compared with the South, where more children combined schooling with economic activities. The explanation of this is not clear; it may be a reflection of regional poverty differences. This finding also coincides with the 1999 poverty profile report, which shows a relatively higher incidence of poverty in Northern Nigeria.

More idle children (participating in neither school nor work) are recorded in Northern than in Southern Nigeria. This is a reflection of delayed enrolment among children in the Northern Zone, and to a larger extent that of the female child. Culture may also contribute to the result because there is high incidence of school-aged children begging for alms in Northern Nigeria. Over all the child activity options, the test of difference between means shows that child activity options of Southern children are significantly different from those of Northern children except for those children combining schooling with economic activity (Appendix Table A1).

Table 4 brings out the activity options of the child in rural and urban areas across the zones in Nigeria. The table shows that there is a wide gap in school enrolment between rural and urban children. This gap widens at an early age, reflecting earlier withdrawal of children from school in rural areas. The urban advantage merits comment. No one would be surprised to see a marked urban advantage because urban households have easier access to school than rural households. With the educational horizon of rural parents so limited, they may lack knowledge or enthusiasm to send their children to school rather 
than work. The table also indicates that participation of schooling children in economic activities increases with the age of the child in all sectors, confirming a higher age as a necessary condition for participation in economic activities.

Table 4: Percentage distribution of child activities in urban and rural Nigeria

\begin{tabular}{llccccccc}
\hline & \multicolumn{2}{c}{ School only } & \multicolumn{2}{c}{ School and work } & \multicolumn{2}{c}{ Work only } & \multicolumn{2}{c}{ Idle } \\
\cline { 2 - 8 } Age & Rural & Urban & Rural & Urban & Rural & Urban & Rural & Urban \\
\hline 5 & 55 & 78 & 13 & 9 & 4 & 1 & 28 & 13 \\
6 & 62 & 86 & 22 & 11 & 4 & 0 & 12 & 2 \\
7 & 63 & 84 & 29 & 15 & 4 & 1 & 4 & 1 \\
8 & 63 & 82 & 31 & 17 & 4 & 1 & 3 & 1 \\
9 & 61 & 85 & 33 & 14 & 5 & 1 & 1 & 1 \\
10 & 57 & 79 & 36 & 20 & 5 & 1 & 1 & 0 \\
11 & 59 & 78 & 37 & 21 & 4 & 1 & 0 & 0 \\
12 & 57 & 79 & 37 & 20 & 5 & 1 & 1 & 0 \\
13 & 55 & 79 & 39 & 20 & 6 & 1 & 1 & 0 \\
14 & 56 & 78 & 37 & 20 & 6 & 2 & 1 & 0 \\
All & 59 & 81 & 31 & 17 & 5 & 1 & 5 & 2 \\
\hline
\end{tabular}

Note: $\mathrm{U}=$ Urban; $\mathrm{R}=$ Rural.

Source: Child Labour Survey, 2001.

The incidence of idling children not only decreases with age, there is also a wide sectoral gap. This gap narrows as the age of the child increases, reflecting early withdrawal of urban children from idling activity. Participation of urban children in full-time work is almost constant in all ages. The participation of children in full-time work activities in rural areas exceeds that of urban children, a result that is probably dictated by poverty status in the two sectors, which is more of a rural than urban problem. This often compels rural children to work in order to enhance household income. Over all the child activity options, the test of difference between means shows that activity options of rural children are significantly different from those of urban children as presented in Appendix Table A1.

In terms of zone, Table 5 shows a marked difference in children's participation in full-time schooling in all the zones, which favours urban children. Table 5 also shows that it is more likely that schooling children in rural areas in Southern will participate in economic activity than those in Northern Nigeria. The overall result of lower participation in school (whether on full-time or part-time basis) in rural than urban in all the zones reflects two things. First is the greater predominance of poverty in rural than urban areas (similar studies have confirmed this; for example, Grootaert, 1998, Nelson, 2000). Second, enterprises such as farming that encourage child participation in economic activities are more common in rural than in urban areas. More idle children are recorded in the rural North than in the rural South. This may be connected to delayed enrolment, disability or lack of interest in education, which are important variables that determine child participation in schooling. 
Table 5: Percentage distribution of child activity options in urban and rural Nigeria

\begin{tabular}{lcccccccc}
\hline & \multicolumn{2}{c}{ School only } & \multicolumn{2}{c}{ School and work } & \multicolumn{2}{c}{ Work only } & \multicolumn{2}{c}{ Idle } \\
\cline { 2 - 9 } Zones & Rural & Urban & Rural & Urban & Rural & Urban & Rural & Urban \\
\hline 1. NC & 59 & 67 & 29 & 30 & 6 & 1 & 6 & 1 \\
2. NE & 43 & 61 & 27 & 29 & 19 & 5 & 11 & 6 \\
3. NW & 54 & 78 & 31 & 18 & 5 & 1 & 10 & 3 \\
4. SE & 63 & 70 & 37 & 30 & 0 & 0 & 0 & 0 \\
5. SS & 56 & 70 & 43 & 29 & 0 & 0 & 2 & 1 \\
6. SW & 90 & 92 & 7 & 7 & 1 & 0 & 2 & 1 \\
\hline
\end{tabular}

Note: $\mathrm{U}=$ Urban; $\mathrm{R}=$ Rural. Zones as above.

Source: Child Labour Survey, 2001.

The age specific differentials in child schooling, work and non-activity are examined in Table 6. This look at age groupings is important in order to ascertain at what school stage the higher participation in economic activities occurs so as to permit appropriate targeting. Children aged 5 to 11 years are assumed to be in primary school, while those aged between 12 and 14 years are assumed to be in junior secondary school (JSS). Although the enrolment of girls is lower than boys over all the age groups, the difference is marginal. Work participation shows a higher and wider gender disparity than for children in neither activity. Participation in work is highest among children in the 5-11 years age group, which includes children who are supposed to be in primary school. Further analysis shows that more children aged between 5 and 11 years participate in full-time school and less in full-time work than any other age group. This group also constitutes the largest cohort of idling children.

Table 6: Activity status of children across gender and age, by per cent

\begin{tabular}{lccc}
\hline Age group & Full-time school & Full-time work & Idle children \\
\hline Boys & & & \\
$5-11$ & 68 & 4 & 5 \\
$12-14$ & 64 & 5 & 0 \\
& & & \\
Girls & 67 & 2 & 6 \\
$5-11$ & 66 & 3 & 0 \\
$12-14$ & & & \\
All children & 67 & 3 & 5 \\
$5-11$ & 65 & 4 & 0 \\
$12-14$ &
\end{tabular}

Source: Child Labour Survey, 2001.

Work activities can be disaggregated further into paid work, unpaid work and domestic work. The results, as presented in Table 7, indicate gender dimensions in specific work 
activities that have interesting similarities and differences. First, there is a significant gender difference in participation in unpaid work and domestic work that increases as the child grows older. It is evident from the table that more female children participate in domestic chores than male. The possible explanation of this is that girls are expected to be future mothers. Therefore, home management, which is mainly domestic chores, is taught to female children early in life. It is also interesting to note that irrespective of gender the children withdraw from household chores as they grow older. Generally, it must be noted that more children participate in paid work at older ages. For example, less than $2 \%$ of the sample 8 -year-olds and $8 \%$ of 14-year-olds participate in paid work. The result is further disaggregated by zones as presented in Table 8 .

Table 7: Percentage distribution of children in different work activities

\begin{tabular}{|c|c|c|c|c|c|c|}
\hline \multirow[t]{2}{*}{ Age } & \multicolumn{2}{|c|}{ Paid work } & \multicolumn{2}{|c|}{ Unpaid work } & \multicolumn{2}{|c|}{ Domestic work } \\
\hline & Male & Female & Male & Female & Male & Female \\
\hline 5 & 1 & 2 & 15 & 6 & 84 & 92 \\
\hline 6 & 1 & 1 & 19 & 12 & 79 & 87 \\
\hline 7 & 1 & 2 & 24 & 11 & 75 & 87 \\
\hline 8 & 2 & 1 & 22 & 12 & 76 & 87 \\
\hline 9 & 2 & 2 & 35 & 14 & 63 & 84 \\
\hline 10 & 2 & 3 & 35 & 16 & 63 & 81 \\
\hline 11 & 7 & 2 & 39 & 17 & 54 & 81 \\
\hline 12 & 5 & 2 & 42 & 24 & 52 & 74 \\
\hline 13 & 7 & 5 & 46 & 20 & 47 & 75 \\
\hline 14 & 6 & 9 & 48 & 24 & 46 & 67 \\
\hline All & 4 & 3 & 34 & 24 & 62 & 73 \\
\hline
\end{tabular}

Source: Child Labour Survey, 2001.

Table 8: Percentage distribution of children in different work activities across zones

\begin{tabular}{lcccccc}
\hline & \multicolumn{2}{c}{ Paid work } & \multicolumn{2}{c}{ Unpaid work } & \multicolumn{2}{c}{ Domestic work } \\
\cline { 2 - 7 } Zones & Male & Female & Male & Female & Male & Female \\
\hline 1. NC & 2 & 3 & 46 & 24 & 52 & 73 \\
2. NE & 4 & 4 & 38 & 17 & 58 & 80 \\
3. NW & 3 & 2 & 20 & 8 & 76 & 90 \\
4. SE & 4 & 5 & 17 & 16 & 79 & 79 \\
5. SS & 29 & 14 & 28 & 23 & 43 & 60 \\
6. SW & 10 & 18 & 27 & 30 & 52 & 64 \\
\hline
\end{tabular}

Zones as above.

Source: Child Labour Survey, 2001.

Further, the table indicates that more children participate in domestic work than any other type of work in all the zones, and to greater extent female children. Moreover, more children participate in unpaid work than in paid work in all the zones. The table 
also shows a gender differential - there are more girls than boys in domestic duties in all zones. However, the size and significance of such gender imbalance is nowhere as large or as pronounced as in Northern zones.

The disaggregation of work activities into full-time domestic work activities and the combination of domestic work with some economic activities is presented in Table 9. The table reaffirms that irrespective of gender, children withdraw from household chores as they get older. The age of the child also associates positively with children combining household chores with work. This indicates that older children are more likely than younger children to combine household chores with some economic activities. The basic difference between these two categories is the inclusion of economic activities, which require older children to participate.

When the gender of the child is considered, however, a more interesting result is revealed. The most striking of these findings is that as the age of the child increases, the participation gap in any of the activities diminishes. For example, percentage differences from the age of 5 and 9 years to 10 and 14 years between participating in domestic chores and combining domestic chores with work are $63 \%$ and $38 \%$, respectively, for females and $48 \%$ and $16 \%$ for males.

Table 9: Percentage distribution of children according to their participation in different household chores

\begin{tabular}{lcc}
\hline Age group & $\begin{array}{c}\text { Domestic chores } \\
\text { only }\end{array}$ & $\begin{array}{c}\text { Domestic chores } \\
\text { and work }\end{array}$ \\
\hline All & 78 & \\
$5-9$ years & 78 & 22 \\
$10-14$ years & & 36 \\
Female & 82 & \\
$5-9$ years & 69 & 18 \\
$10-14$ years & & 31 \\
Male & 74 & \\
$5-9$ years & 8 & 26 \\
$10-14$ years & & 42 \\
\hline
\end{tabular}

Source: Child Labour Survey, 2001.

\section{Parental and household characteristics and the activity status of children}

any studies have identified parental characteristics as one of the factors influencing 1 the decision of the parents to involve their children in economic activities. The major parental characteristics such as employment, education and presence of the parents in the household are discussed below. 


\section{Parental employment and child activity options in Nigeria}

There has been substantial debate over whether children and parents (particularly mothers) are substitutes or complements in economic activity. Proponents of the complementary argument assert that when mothers participate in the labour force, children take over household work from mothers; that is, mothers and children are complementary in economic activity (domestic work) (Levison, 1991). On the other hand, proponents of the substitution argument (e.g., Basu and Van, 1998) say that when mothers are more available for market work, children are removed from the labour market. This results in a decrease in the labour force participation rate of children and an increase in school attendance. Thus, parents (or mothers) and children are substitutes in economic activities. In this section, we explore the empirical evidence on this issue using Nigerian child labour survey data (see Table 10).

Table 10: Activity status of children by parents' primary occupational status (per cent)

\begin{tabular}{|c|c|c|c|c|}
\hline & School & Work & School/work & Idle \\
\hline \multicolumn{5}{|l|}{ Male children } \\
\hline \multicolumn{5}{|l|}{ Fathers } \\
\hline Farming & 59 & 7 & 29 & 5 \\
\hline Non-farming & 78 & 1 & 19 & 2 \\
\hline \multicolumn{5}{|l|}{ Mothers } \\
\hline Farming & 62 & 6 & 25 & 6 \\
\hline Non-farming & 80 & 1 & 17 & 1 \\
\hline \multicolumn{5}{|l|}{ Female children } \\
\hline \multicolumn{5}{|l|}{ Fathers } \\
\hline Farming & 58 & 4 & 31 & 6 \\
\hline Non-farming & 74 & 1 & 23 & 2 \\
\hline \multicolumn{5}{|l|}{ Mothers } \\
\hline Farming & 64 & 2 & 29 & 4 \\
\hline Non-farming & 0 & 27 & 2 & \\
\hline \multicolumn{5}{|c|}{ Parents - All children } \\
\hline Farming & 59 & 6 & 29 & 6 \\
\hline Non-farming & 67 & 3 & 26 & 4 \\
\hline
\end{tabular}

Source: Child Labour Survey, 2001.

Table 10 shows that children from farming households are more likely to participate in economic activity than children from non-farming households. This is expected because farming households are assumed to be poorer and less educated than non-farming households. In addition, farming in developing countries is at a rudimentary stage, usually peasant farming, which is highly labour intensive. Since peasant farmers are poor and may not afford to hire labour, they resort to their own labour - and that of their children. It is also expected that children from non-farming households participate more in 
schooling, and less in work and idling activities. This is because it is expected that in most cases the head of a non-farming household has acquired some formal education and is therefore more aware of the long-term implication of allowing children to get involved in economic activities.

The table also presents the influence of the gender of the household head on the activity options of the child. There is higher incidence of school enrolment and consequent reduction in economic activities by children when the mother is employed in non-farming activities than when the father is employed in non-farming activities. Canagarajah and Coulombe (1997), who say that when mothers are more available for market work, children are removed from the labour market, support this.

It should also be noted that when both parents are employed in non-farming activities, there is increased school enrolment and less participation in work or idling activities of male children than female children.

\section{Education of the parents and child activity options}

It is often postulated that educational attainment of parents plays a key role in determining a child's work. Educated parents are expected to dissuade children from engaging in labour activity because they usually realize the importance of education, in particular the long-term (monetary) returns to human capital accumulation. The empirical evidence on this issue is summarized in Table 11.

The table shows that the education attainment of the household head has a significantly negative impact on the incidence of child labour in Nigeria. The descriptive statistics show that $30 \%$ of boys or girls whose household heads attained less than secondary school participate in work activities. Furthermore, 5\% and 6\% of girls and boys, respectively, whose household heads attained less than secondary school participate in neither school nor work activity (idling). On the other hand, $23 \%$ of girls and $25 \%$ of boys belonging to families in which the head attained post-secondary school engaged in the labour force. Less than $2 \%$ of girls and $1 \%$ of boys whose household heads attained post-secondary participate in neither work nor schooling activity (that is, idling).

The table also shows that a mother's education has greater impact on encouraging children to participate in schooling and discouraging their participation in economic activities than the father's education. The table also reveals that mother's education reduces the incidence of idling children. A possible explanation for this is that the mother's time is an input into the education (production of human capital) of her children, and that the mother's own level of education raises the productivity of this input. According to this argument (Behrman et al., 1999), the mother's own level of education increases her services as a home tutor rather than as a market labourer and thus raises the return to the time that her children spend in education. This finding is supported by Cartwright and Patrinos (1999), who say that increased education of mothers implies that better educated mothers have greater opportunities for paid employment outside the home, hence increasing household income, and has greater probability of a child attending school. By increasing family income, the mother's employment reduces the need to rely on the child's labour. 
Table 11: Activity status of children by parental education (per cent)

\begin{tabular}{|c|c|c|c|c|}
\hline & School & Work & School/Work & Idle \\
\hline \multicolumn{5}{|l|}{ Boys } \\
\hline \multicolumn{5}{|l|}{ Father's education } \\
\hline Illiterate & 63 & 6 & 25 & 6 \\
\hline Primary & 68 & 2 & 27 & 3 \\
\hline Secondary & 73 & 2 & 23 & 2 \\
\hline Post-secondary & 77 & 1 & 20 & 2 \\
\hline \multicolumn{5}{|l|}{ Mother's education } \\
\hline Illiterate & 64 & 5 & 25 & 5 \\
\hline Primary & 68 & 2 & 28 & 3 \\
\hline Secondary & 77 & 2 & 19 & 2 \\
\hline Post-secondary & 78 & 3 & 19 & 0 \\
\hline \multicolumn{5}{|l|}{ Girls } \\
\hline \multicolumn{5}{|l|}{ Father's education } \\
\hline Illiterate & 62 & 4 & 26 & 8 \\
\hline Primary & 66 & 1 & 29 & 4 \\
\hline Secondary & 72 & 1 & 24 & 3 \\
\hline Post secondary & 77 & 1 & 20 & 1 \\
\hline \multicolumn{5}{|l|}{ Mother's education } \\
\hline Illiterate & 63 & 4 & 27 & 7 \\
\hline Primary & 67 & 1 & 29 & 4 \\
\hline Secondary & 76 & 1 & 21 & 2 \\
\hline Post-secondary & 80 & 2 & 17 & 1 \\
\hline Parents' education & Girls & & & \\
\hline No education & 64 & 6 & 24 & 6 \\
\hline Primary & 66 & 3 & 27 & 3 \\
\hline Secondary & 70 & 3 & 24 & 2 \\
\hline \multirow[t]{2}{*}{ Post-secondary } & 75 & 2 & 21 & 2 \\
\hline & Boys & & & \\
\hline No education & 63 & 4 & 26 & 7 \\
\hline Primary & 65 & 1 & 29 & 4 \\
\hline Secondary & 70 & 2 & 25 & 3 \\
\hline Post-secondary & 73 & 2 & 23 & 1 \\
\hline
\end{tabular}

Source: Child Labour Survey, 2001. 


\section{Presence of parents and its impact on child activity options}

The gender-specific activity rates across the presence of parents in a household are presented in Table12. The survey shows that the mother's presence reduces the participation of both male and female children in exclusive work activity and increases their participation in school enrolment more than the father's presence. In addition, the presence of mothers decreases the number of male children in idling activity more than it does that of female children.

Table 12: Activity status of children by presence status of parents in household (per cent)

\begin{tabular}{lcccc}
$\begin{array}{l}\text { Presence status } \\
\text { of the parents }\end{array}$ & School only & Work only & Work/School & Idleness \\
\hline $\begin{array}{l}\text { Boys } \\
\text { Father present }\end{array}$ & 71 & 2 & 26 & 2 \\
Mother present & 72 & 1 & 26 & 1 \\
Both parents present & 65 & 5 & 26 & 4 \\
Girls & & & & \\
Father present & 68 & 1 & 29 & 2 \\
Mother present & 72 & 1 & 25 & 2 \\
Both parents present & 65 & 3 & 27 & 5 \\
& & & & \\
All children & 69 & 2 & 27 & 2 \\
Father present & 72 & 1 & 26 & 2 \\
Mother present & 65 & 4 & 26 & 5 \\
Both parents present & & & & \\
\hline
\end{tabular}

Source: Computed from Child Labour Survey, 2001.

The results also indicate a further gender differential among schooling children participating in work activity when mother or father is present in the household. The number of schooling male children who participate in work activity when the mother is present in the household and of female children when the father is present is greater than when the whole group of children is considered. The table also shows that the presence of the father in the household has a stronger impact on increasing the participation of male children in school than on that of female children.

It is a surprise that the presence of both father and mother in a household increased the participation of children in all work activities and reduced their participation in school more than when either the mother or the father is present. The explanation of this is difficult; it may be because the presence of both parents increases both household size and family expenditure, which compels their children to work for additional income to improve the welfare of the household. Another explanation is that there may be high illiteracy rate among parents in Nigeria. 


\section{Household headed by children in Nigeria}

A household headed by a child is an indication of early death of the parents and lack of concern for the immediate family. The Child Labour Survey of 2001 examines this issue although not in detail. The survey found that children aged between 5 and 14 years head a sizeable number of households in Nigeria. The empirical evidence is summarized in Table 13, which gives the percentage of households headed by children across gender in urban and rural Nigeria. The table shows that there are more child-headed households in urban than rural areas. This may be a reflection of rural-urban migration in Nigeria. It could also be a result of higher prevalence of HIV/AIDS, which left many children orphaned and automatic household heads. The high incidence of households headed by children in urban areas is also attributed to the problem associated with early death of parents and high poverty incidence in rural Nigeria, which may force the children to migrate to urban areas and become household heads. Many of these children often move without their family, which automatically makes them the household head in the new environment.

Table 13: Households headed by children across gender and sectors

\begin{tabular}{lccc}
\hline Sectors & Male head & Female head & All children \\
\hline Rural & $0.03 \%$ & $0.05 \%$ & $0.04 \%$ \\
Urban & $0.07 \%$ & $0.05 \%$ & $0.06 \%$ \\
\hline
\end{tabular}

Source: Child Labour Survey, 2001.

Even though the percentage looks numerically small, when these figures are weighted it shows that a sizeable number of children fall within into this category in Nigeria. Specifically, out of 38,071,349 children in Nigeria, the total number of households headed by children translates to 9,125 and 7,685 in rural and urban areas, respectively, as well as a total of 8,579 male-headed and 8,232 female-headed households in Nigeria.

There is need to study in detail what causes the incidence of households headed by children in Nigeria. The questionnaire used in the Child Labour Survey of 2001 is not exhaustive in investigating this type of children.

\section{Gender of household head and child activity options in Nigeria} Much research has studied the association between the gender of a household head and the child activity options in developing countries. The Child Labour Survey found the relationship between the activity option of the children and the gender of household head that is presented in Table 14. 
Table 14: Percentage distribution of children according to their activity options with different household heads

\begin{tabular}{lcc}
\hline Activities & Female-head & Male-head \\
\hline Work & 8.08 & 7.91 \\
School work & 27.95 & 25.39 \\
School & 51.71 & 54.90 \\
Idle & 3.92 & 3.80 \\
Paid work & $4.29^{\star}$ & $2.01^{*}$ \\
Unpaid work & 16.59 & 22.26 \\
Domestic chores & $22^{*}$ & $78^{*}$ \\
\hline
\end{tabular}

* Significant at $5 \%$ probability level.

Source: Computed from Child Labour Survey, 2001.

Table 14 also shows that although there is equal school enrolment in the two types of household, children's participation in work differs. Children from female-headed households are more likely to work or combine schooling with work than children from male-headed households. This may be a reflection of the financial burden faced by femaleheaded households, as acknowledged in literature (Patrinos and Psaharopoulos, 1997), which makes it imperative for children from female-headed families to participate in economic activities, especially paid work, to augment the household income. It must also be noted that children from male-headed households participate more in unpaid work than those of female-headed households. The reason for this is not clear, but may be attributed to the existence of more farmland in the male-headed families, which is relatively small in female-headed households. It is also important to note that there is more participation of children from male-headed households in domestic chores than those from female-headed households. This is expected because there is a perfect substitution between presence of mothers and children in participation of domestic chores.

\section{Household size and child activity options}

The literature has clearly established that larger household sizes reduce children's school enrolment and increase their participation in economic activities (Grootaert, 1998). Table 15 shows that the association between household size and children's activity option confirms the findings of earlier studies. The possible explanation for this is that a larger household size reduces the income of the household, thereby increasing the chances of a child participating in economic activities especially in paid work. Although the relationship between household size and idling children is less clear, the household size of 5-7 has the highest incidence of children in this category. Overall, the analysis suggests that children from larger households do not always go to school; much of their time is devoted to work activity. 
Table 15: Activity options of children and household size (per cent)

\begin{tabular}{lccc}
\hline & & Household size & \\
\hline Activity options & $<4$ & $5-7$ & 8 and above \\
\hline Work & 2 & 3 & 4 \\
School & 74 & 68 & 63 \\
School/work & 21 & 24 & 30 \\
Idle & 3 & 5 & 3 \\
\hline
\end{tabular}

Source: Computed from Child Labour Survey, 2001.

\section{Children and work}

Children enter the labour force at different ages and spend varying times at work. Their poverty status, income and contribution to the family income also vary considerably, as does their option to work full-time or part-time. Details of these and other aspects of child labour are presented in the following sections.

\section{Age at participation of children in work activities}

The age of participation of children in work activities across zone, gender and sector is presented in Table 16. Over all the zones, as well as sectors and genders, children enter paid work at an older age than unpaid work. Further, children from Southwest zone enter paid work (12.8 years) at later age than any other zone in Nigeria. Although children from Northern zones enter into work activity at a younger age than those in the South, male children enter into paid work at an older age than female children irrespective of location. In addition, male children enter unpaid work activities at a younger age than their female counterparts.

Table 16: Distribution of children according to age (years) of participation in work activities across zones, gender and sectors

\begin{tabular}{lrrl}
\hline Zones & Paid & Unpaid & All \\
\hline 1. NC & & & 7.7 \\
2. NE & 9.8 & 7.8 & 7.2 \\
3. NW & 9.5 & 7.4 & 8.0 \\
4. SE & 11.2 & 7.6 & 7.8 \\
5. SS & 10.7 & 8.6 & 8.3 \\
6. SW & 12.8 & 9.5 & 9.9 \\
Rural & 12.2 & 12.0 & 7.7 \\
Urban & 10.9 & 7.6 & 8.8 \\
Male & 11.2 & 10.7 & 7.8 \\
Female & 11.4 & 7.8 & 8.0 \\
All & 10.5 & 8.2 & 7.9 \\
\hline
\end{tabular}

Zones as above.

Source: Computed from Child Labour Survey, 2001. 
Male children enter the paid work force at older ages than female children, but the average age at which these children enter the labour force - paid or unpaid - shows that female children start economic activities at an earlier age than male children. The average age at which these children enter the labour force first is 11 years and 7.9 years for paid and unpaid works, respectively, irrespective of gender and locations.

In summary then, the table shows that there are gender, zonal and sectoral differences in the average age of participation in paid and unpaid work in Nigeria. Even though children in Nigeria enter the work force at an average age of 7.9 years, a higher age is required for them to participate in paid work (11.0 years) than unpaid work ( 7.9 years). The difference in ages for paid and unpaid work is higher in rural areas than urban areas.

\section{Time allocation to work activities by children}

Some studies consider 20 hours of work per week as the critical threshold beyond which the education of the child starts being significantly affected (Fallon and Zafiris, 1998). The number of hours spent by different categories of children in work activities excluding domestic works is presented in Table 17. It is evident from the table that the number of hours increases with the age of the children. Further, the table shows that hours spent in work activities differ across zones. Specifically, children aged between 5 and 9 years spent approximately 20 hours at work in a week in Northwest, Northeast and Southwest zones of Nigeria. This is certainly a reason to believe that the educational performance of these children is impaired - if they are in school at all. This finding is supported by studies elsewhere in developing countries that long hours of work affect the physical and mental development of children (Nelson, 2000).

Table 17: Hours spent working per week across ages and zones in Nigeria

\begin{tabular}{lccc}
\hline Zones & $\mathbf{5 - 9}$ (yrs) & $\mathbf{1 0 - 1 4}$ (yrs) & $\mathbf{5 - 1 4}$ (yrs) \\
\hline 1. NC & 17.93 hours & 21.55 hours & 21.64 hours \\
2. NE & 19.93 & 23.65 & 23.23 \\
3. NW & 19.91 & 23.09 & 24.67 \\
4. SE & 15.89 & 22.27 & 20.52 \\
5. SS & 11.24 & 14.54 & 15.11 \\
6. SW & 23.14 & 22.77 & 27.96 \\
All & 17.69 & 20.91 & 21.51 \\
\hline
\end{tabular}

Source: Computed from Child Labour Survey, 2001.

On the average, children aged 5-9 years spent approximately 17.69 hours in a week in work activities. Over all except the South-South zones in Nigeria, children aged between 10 and 14 years spent more than 20 hours at work. However, it is important to disaggregate the number of hours spent by children according to their level of commitment in economic activities.

According to Table 18, over all the sectors and genders, hours spent working per week by exclusive child labourers are statistically different from those of schooling children except male children and those aged between 5 and 9 years in urban areas. This 
could be attributed to the exclusion of schooling children from participation in work activity during their school hours. They therefore spent significantly fewer hours in work activities than working children. Exclusive child labourers in rural areas spent more hours per week (20.24 hours) than those in urban areas (16.45 hours) in economic activities. This is presumably because of child involvement in agricultural activities, which are taxing and virtually non-existent in urban areas. Schooling children participating in economic activities spent almost the same number of hours in both age groups (16.14 hours and 16.67 hours in a week, respectively). For full-time work, however, the older children spent more hours in urban areas than in rural areas.

Table 18: Hours spent in a week on part or full-time work

\begin{tabular}{lcccc}
\hline & \multicolumn{2}{c}{5} & \multicolumn{2}{c}{$\mathbf{1 0 - 1 4}$ years } \\
\cline { 2 - 5 } Gender/Sector & Full-time work & Part-time work & Full-time work & Part-time work \\
\hline Male & 19.52 hours & 16.36 hours & 27.28 hours & 17.50 hours $^{*}$ \\
Female & 20.97 & $15.60^{\star}$ & 30.48 & $17.30^{\star}$ \\
Rural & 20.24 & $15.62^{\star}$ & 27.31 & $17.66^{\star}$ \\
Urban & 16.45 & 17.47 & 38.15 & $16.63^{\star}$ \\
All & 20.01 & $16.14^{\star}$ & 28.41 & $16.67^{\star}$ \\
\hline
\end{tabular}

* indicates significant at 5\% probability level.

Source: Computed from Child Labour Survey, 2001.

Table 19 shows that there is also a gender differential in the number of hours children spend in a week in economic activities. Exclusive female child labourers spent more hours in work (26.62 hours) than their male counterparts (23.17 hours), while full-time workers in rural areas spent more time working (30.91 hours) than urban children (24.04 hours). The possible explanation for the latter is the existence of agricultural activities, which take more time than other economic activities engaged in by children. In view of this result, we can rightly say that rural child labourers are more likely to have illness or injuries than their urban counterparts.

Table 19: Hours spent working in a week by category of children

\begin{tabular}{lccc}
\hline \multirow{2}{*}{ Details } & \multicolumn{3}{c}{ Category } \\
\cline { 2 - 4 } & Work only & School/work & All children \\
\hline Male & 23.17 hours & 17.12 hours $^{*}$ & 21.79 hours \\
Female & 26.32 & $16.68^{*}$ & 21.08 \\
Rural & 30.91 & $16.93^{*}$ & 21.22 \\
Urban & 24.04 & $16.91^{*}$ & 22.65 \\
Overall & 24.61 & $16.93^{*}$ & 21.51 \\
\hline
\end{tabular}

Note: * significant at $5 \%$ probability level.

Source: Computed from Child Labour Survey, 2001. 


\section{Poverty and child activity options}

It seems obvious that household welfare and child labour should be closely correlated. At a micro-level, this suggests that if a household is too poor to survive without children contributing to the economic activities of the household, children will be induced to engage in either market or home work, which could lead to harmful effects on long-run human capital accumulation and has potential for perpetuating poverty across generations. Our perusal of the Child Labour Survey yielded a number of interesting issues (see Tables 20 and 21).

Table 20: Child activity options and household poverty status

\begin{tabular}{lccc}
\hline \multirow{2}{*}{ Poverty status } & \multicolumn{3}{c}{ Child activity options } \\
\cline { 2 - 4 } & School only & Work only & School/Work \\
\hline Core poor & $17.6 \%$ & $51.5 \%$ & $30.9 \%$ \\
Moderate poor & 20.7 & 61.4 & 17.9 \\
Non-poor & 80.6 & 1.1 & 16.7 \\
\hline
\end{tabular}

Note: The core poor constitute households whose mean per capita income is one-third or less of mean per capita income, moderate poor constitute households whose mean per capita income is more than one-third but less than two-thirds, and non-poor constitute households whose mean per capita income is two-thirds and above.

Source: Computed from Child Labour Survey, 2001.

Table 20 brings out the association between child activity options and household poverty status. The table shows that there is relatively higher incidence of children combining economic activities with schooling in poorer households. More children in non-poor households than in poor families are enrolled in school. This has been supported in literature (Neilsen, 1998; Patrinos and Psacharopoulos, 1995, in Paraguay). The likely explanation is that as household income decreases, there is greater need for children to work to augment household income, thus suggesting poverty as a driving force in children's participation in economic activity.

In terms of expenditure quintiles, Table 21 shows a positive relationship between increased child participation in economic activities and expenditure quintiles of the household. For example, 5\% of sampled children from the lowest quintile engaged in full-time work compared with only $2 \%$ of the same category of children in the highest quintile. In addition, there is a marked difference in participation in work activity by children whose households fall within the second and third quintile. This seems to suggest that the poverty status of the household begins having a serious effect on child participation in economic activities from the third quintile. For the lowest expenditure quintile, 59.7\% and $9.4 \%$ of children, respectively, participate in full-time schooling and idling, compared with $70.9 \%$ and $2 \%$ of children belonging to highest expenditure quintile. In order words, the probability of children being economically active rises if a household belongs to the lowest expenditure quintile. 
Table 21: Distribution of child labour activities across household income quintiles

\begin{tabular}{lcccc}
\hline Quintile & School only & Work & School/work & Idling \\
\hline 1st quintile & 59.7 & 5.0 & 25.9 & 9.4 \\
2nd quintile & 65.6 & 4.4 & 25.1 & 5.0 \\
3rd quintile & 66.0 & 3.8 & 27.3 & 3.0 \\
4th quintile & 68.0 & 3.1 & 26.5 & 2.4 \\
5th quintile & 70.9 & 1.8 & 25.3 & 2.0 \\
\hline
\end{tabular}

Source: Computed from Child Labour Survey, 2001.

\section{Earnings from child labour}

Many studies have argued the importance of child labour income in alleviating household poverty. In some cases, they found that children contribute about one-third of household income, which is enough to raise a household above the poverty line. Other studies have reported that income from child labour may enhance household welfare, especially by helping poor families pay for transportation to school, school materials and uniform as well as other schooling expenses.

The Nigerian Child Labour Survey uncovered differences in earnings from child labour across zones in Nigeria. Children from North Central and Northwest earn $\mathrm{N2,267}$ and N5,514, respectively, per week, while children from Northeast and Southeast earn less

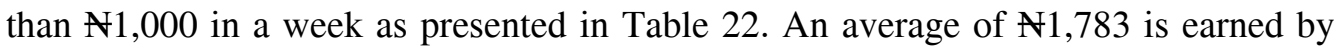
children in Nigeria per week irrespective of gender, zone and sector. This is enough to improve the household income. However, the long-run effect of the participation of children in economic activities and where this income is channelled are important. The income is well utilized if it is channelled into schooling expenses for the child. There is need for more study into how child labour income is utilized.

Table 22: Earnings of children across zones and activity options

\begin{tabular}{lc} 
Zones & Earnings per week (N) \\
\hline 1. NC & 2,267 \\
2. NE & 699 \\
3. NW & 5,514 \\
4. SE & 832 \\
5. SS & 1,993 \\
6. SW & 1,178 \\
All & 1,783 \\
\hline
\end{tabular}

Note * significant at $5 \%$ probability level.

Source: Computed from Child Labour Survey, 2001.

In Nigeria, children's potential future earnings, as well as future poverty, may be affected by their entry into the labour market at a younger age. Besides the physical and mental risks to which these children are exposed, which affect their capacity to work and 
earn income in the future, their income prospects may be affected by their lower educational attainment. Table 23 shows that although earnings increase with age, children are likely to suffer the consequences of early entry into the labour force. This is especially true for children who began working at the age category of 5-9 years; they earn 47\% less than those who began working at 10-14 years. It may be surprising that as the age of schooling children increases, their earnings significantly drop, but there are two possible explanations. First, it may be that hours spent in economic activities do not always translate to income. Most of the time children work as unpaid labourers, which is not monetarily remunerated. Second, people at a younger age, especially schooling children, may not be ashamed of what they do to support their families. As children grow older, however, especially schooling children, they become more selective about the type of work they do to avoid embarrassment from their peer groups. This means that how much they earn depends not only on their ability to work, but also on their ability to tolerate insult and humiliation, which has a negative association with age. For the exclusive child labourers, on the other hand, embarrassment from peers may be of less consequence because they must work to help the family. The determinants of what they earn therefore depend solely on their ability to work, which indirectly depends on the age of the child.

Table 23: Child earnings in naira across age groups

\begin{tabular}{lccc}
\hline & \multicolumn{3}{c}{ Category } \\
\cline { 2 - 4 } Age group & $\begin{array}{c}\text { Exclusive child } \\
\text { labourers }\end{array}$ & School work & All \\
\hline $5-9$ years & 146.36 & $2,823.47$ & $2,126.69$ \\
$10-14$ & $4,946.07$ & 495.22 & $1,125.18$ \\
All & $2,976.96$ & $1,149.22$ & $1,782.65$ \\
\hline
\end{tabular}

Source: Computed from Child Labour Survey, 2001.

In terms of child earnings across gender and sector, Table 24 shows that male and female children earn an average of $\$ 2,028.96$ and $\mathrm{N} 1,274.00$, respectively. Also, $\mathrm{N} 1813.67$ and $\mathrm{N} 1659.79$, on average, was earned by children in rural and urban areas, respectively, in a week. Irrespective of their location, gender and age, children earn on

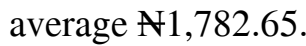

The most distinctive evidence observed from the data is the differential in the earnings of male and female children. Although this is not conclusive in confirming that female children work more hours for less pay, it is a clear indication that higher wage rates favour male children, and that wage discrimination begins at an early age in Nigeria. It is

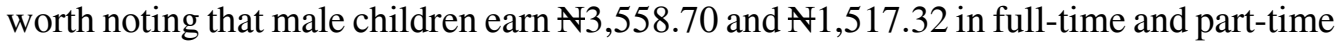
paid work, respectively, while female children earn $\$ 1,496.15$ and $\$ 387.64$. The higher earnings of children in rural areas than in urban areas indicate that remuneration is better in rural areas than in urban areas for children. This may also explain the poverty differences in rural and urban areas. 
Table 24: Child earnings per week across gender, categories and sectors in Nigeria, in naira

\begin{tabular}{lccc}
\hline Details & $\begin{array}{c}\text { Full-time } \\
\text { workers }\end{array}$ & $\begin{array}{c}\text { Part-time } \\
\text { workers }\end{array}$ & All children \\
\hline Male & $3,558.70$ & $1,517.32$ & $2,028.96$ \\
Female & $1,496.15$ & 387.64 & $1,274.00$ \\
Rural & $3,007.78$ & 1,324 & $1,813.67$ \\
Urban & $2,767.33$ & 433.30 & $1,659.79$ \\
Average & $2,976.96$ & $1,149.22$ & $1,782.65$ \\
\hline
\end{tabular}

Source: Computed from Child Labour Survey, 2001.

As indicated in Table 25, the contribution of children's earnings to household income ranges from $3.5 \%$ to $38 \%$. Contributions of children from Southeast and Northwest zones to household income are relatively high. Although the monetary value of children's work is relatively high in Southwest ( $\mathbb{2} 29 /$ hour), the contribution to household income is about the lowest in the zones. The monetary value of children's work per hour is lowest in Northeast ( $\mathrm{N} 5 /$ hour) and Northwest ( $\mathrm{N} 8$ /hour) zones of Nigeria. This is an indication of a relatively high level of exploitation of children in these two zones.

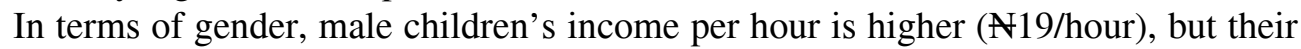
contribution to household income is lower. This seems to suggest that the girls' income is more responsive to the welfare of the family than the boys'. Other studies have actually shown that most male children do not always give their income to their parents (Glick and Sahn, 1997).

Table 25: Amount contributed by children and its percentage of the household income

\begin{tabular}{lcc} 
Zones & $\begin{array}{c}\text { Child's income } \\
\text { per hour (N) }\end{array}$ & $\begin{array}{c}\text { Child's income to household } \\
\text { income (Per cent) }\end{array}$ \\
\hline 1. NC & 13 & 3.5 \\
2. NE & 5 & 9.7 \\
3. NW & 8 & 17.7 \\
4. SE & 10 & 38.0 \\
5. SS & 13 & 12.8 \\
6. SW & 29 & 10.7 \\
Male & 19 & 14.5 \\
Female & 14 & 19.1 \\
Rural & 19 & 16.0 \\
Urban & 17 & 9.3 \\
\hline
\end{tabular}

Source: Computed from Child Labour Survey, 2001.

In terms of location, the result shows that children from rural areas earn more income per hour and contribute more to the household income than their urban counterparts. This is attributed to a higher poverty incidence in rural than urban Nigeria (this is also supported by the literature, as in FOS, 1999). It can be concluded that income from rural children makes a more significant contribution to household income than that of urban children. 


\section{Exclusive child labourers}

These are children engaged in full-time economic activities in the last 12 months as reported by the survey. According to the Child Labour Survey, most working children about $80 \%$ of male workers and $79 \%$ of female workers - dropped out in primary school. The percentage dropout in primary grades $4-6$ is higher for males than females. (See Table 26.)

Table 26: Stages of dropout of children (per cent)

\begin{tabular}{lccc}
\hline Stages & Male & Female & All children \\
\hline Below primary 4 & $20.6 \%$ & 21.1 & \\
Primary 4-6 & 59.0 & 57.8 & 20.9 \\
Below JSS III & 5.5 & 6.5 & 67.4 \\
JSS completed & 6.0 & 3.5 & 4.8 \\
SSS I and SSS II & 1.3 & 1.9 & 1.6 \\
SSS attempted but not passed & 1.8 & 1 & 1.4 \\
SSS passed & 5.8 & 8.7 & 7.3 \\
\hline
\end{tabular}

Source: Computed from Child Labour Survey, 2001

But many children do not go to school at all, as Table 27 makes clear. The major reasons for non-participation of children in school are lack of interest on the part of both the parents and the children, poverty, lack of school in the vicinity, and underage. However, poverty, non-existence of a school in the vicinity and underage apply more to male children than female children, while lack of interest on the part of parents is a more important reason for female children than for their male counterparts. The fact that the interest of parents matters more for female than male children reflects the importance parents attach to the education of their male children, as well as the expectation that girls will marry early and leave home. Another reason for the lack of interest in education is because education in Nigeria is seen as a business with a long gestation period and low return. This is due partly to orientation and partly to experience. These results also re-echo the many studies showing that poverty and lack of schools drive children into economic activities (Basu, 1998; Glick and Sahn, 1997).

Exclusive child labourers work mostly in the morning (29\%) and/or in the afternoon $(28 \%)$. Fewer children participate in work all through the day $(6 \%)$ and afternoon through evening (4\%) as presented in Table 28. A possible explanation of this is that a majority of the children may be engaged in hawking activity, which is usually done during the peak business periods (late morning and afternoon). This suggests the need for appropriate targeting of these children (e.g., flexible school hours). 
Table 27: Reasons for never being in school

\begin{tabular}{lccc}
\hline Reasons & Male (\%) & Female (\%) & All children \\
\hline Parents poor & 10 & 9 & 9 \\
Parents not interested & 36 & 41 & 39 \\
Parent's sickness & 2 & 2 & 2 \\
No school in vicinity & 22 & 16 & 19 \\
Not interested & 8 & 10 & 9 \\
Poor health & 2 & 3 & 3 \\
Under age & 20 & 19 & 19 \\
\hline
\end{tabular}

Source: Computed from Child Labour Survey, 2001.

Table 28: Percentage distribution of exclusive child labourers according to the time of the day worked

\begin{tabular}{lc} 
Time of the day & Per cent \\
\hline Morning & 29 \\
Afternoon & 28 \\
Evening & 19 \\
Morning and afternoon & 7 \\
Morning and evening & 7 \\
Afternoon and evening & 4 \\
All day along & 6 \\
\hline
\end{tabular}

Source: Computed from Child Labour Survey, 2001.

Many families have no alternative other than to send their children to work because they see their earnings as an input into family survival. Table 29 shows the type of economic activities engaged in by exclusive child workers across gender in Nigeria. The table shows that common economic activities of male children are farming, hawking and water fetching, while for females common paid work activities are water fetching, domestic sweeping and hawking. The table also shows that more female children participate in hawking than male children, while male children dominate in such activities as brick laying labourers, scavenging, bus conducting and load carrying. This shows that male children are more involved in hard labour and more risky work than their female counterparts.

Reasons for participating in work are many, with $34.3 \%$ of children doing so in order to supplement household income. Further analysis shows that most children are paid at piece rates $(61 \%)$ as presented in Table 30 . This type of rate puts these children in the category of casual workers and makes it possible to conceal the conditions under which the work is carried out. Given the irregular nature of such remuneration, the idea of wage negotiation becomes meaningless and leaves the financial compensation up to the employer alone. 
Table 29: Percentage distribution of type of activities by exclusive child labourers across gender

\begin{tabular}{lcc}
\hline Types of paid work & Male & Female \\
\hline Brick laying labourers & $6 \%$ & $1 \%$ \\
Scavenging & 4 & 2 \\
Water fetching & 51 & 49 \\
Domestic sweeping & 23 & 38 \\
Bus conductor & 21 & 10 \\
Load carrying & 23 & 10 \\
Hawking & 33 & 37 \\
Farming & 43 & 27 \\
\hline
\end{tabular}

Note: Multiple responses were recorded.

Source: Computed from Child Labour Survey, 2001.

Table 30: Percentage distribution of children according to mode of payment

\begin{tabular}{lc}
\hline Mode of payment & Per cent (\%) \\
\hline Piece rate & 61 \\
Hourly & 9 \\
Weekly & 17 \\
Monthly & 13 \\
\hline
\end{tabular}

Source: Computed from Child Labour Survey, 2001.

The survey also shows that in the ultimate stage of exploitation, payment is symbolic or nonexistent, or supplied in kind: food, lodging, or "presents" to the child or the family. Most children in Nigeria derived no benefit from their employer (34\%). In some areas, however, their employers gave them "free" meals (25\%) (see Table 31). In addition, there is evidence in the literature that child labourers cannot form a union to press for their demands; therefore, they are subjected to all types of exploitation and deprivation (Blunch and Verner, 2000).

Table 31: Benefit derived from employer by children in Nigeria by gender

\begin{tabular}{lcc}
\hline Benefits & Male & Female \\
\hline Paid holidays & $2 \%$ & $13 \%$ \\
Paid sick leave & 1 & 2 \\
Social security insurance & 1 & 0.5 \\
Bonus & 3 & 1 \\
Free uniform & 4 & 3 \\
Free meals & 26 & 21 \\
Subsidized meals & 3 & 2 \\
Free transport & 9 & 7 \\
Subsidized transport & 2 & 1 \\
Free lodging & 10 & 14 \\
Subsidize lodging & 2 & 0.5 \\
No benefit at all & 35 & 33 \\
Subsidized uniform & 2 & 2
\end{tabular}

Source: Computed from Child Labour Survey, 2001. 


\section{Part-time child labourers}

These are the categories of children who combine schooling with some economic activities. The survey shows that most schooling children participate in work activities after school periods (80\%), which suggests that most children who combine work with schooling are involved in hawking activity. This activity may not be harmful to their school attendance, but it may impair their educational performance. In addition, hawking may expose the children to inherent dangers like accidents, assault and prostitution. Although this survey did not cover the hazards associated with child labour, the picture of the impact of child labour on educational performance becomes clear when we look at the number of school days lost per week because of work activities by children. This is presented in Table 32 .

Table 32: Number of school days lost due to work

\begin{tabular}{lc}
\hline Number of days & Per cent \\
\hline One day & 27 \\
Two days & 10 \\
Three days & 3 \\
Four days & 25 \\
\hline
\end{tabular}

Source: Computed from Child Labour Survey, 2001.

The table shows that most schooling children lost at least one day (27\%), and some as many as four days a week due to economic activities. It is pathetic that a full quarter $(25 \%)$ of schooling children lost four days in a week due to their participation in work activities.

\section{Econometric methodology}

$\mathrm{T}$ The basic theory underlying this study is the household utility model. A complete model of household choice decisions posits that the household chooses a particular child activity option because of utility derived from it. If we assume a unitary household model as suggested by Strauss, Mwabu and Beegle (2000), the probability that household " $h$ " chooses alternative source of " $j$ " is equal to the probability that the utility derived from using " $\mathrm{j}$ " is greater than any other use. In this case, we want to assume that schooling and working decisions of children are independent. In addition, the choice decision of the household is determined by a vector of child, parent and household characteristics, as well as regional and community dummies. The reduced form of the econometric model is explained below.

The decision to send a child to work is described by the following latent variable model:

$$
W_{i}^{*}=X_{1 i} \beta_{1}+\varepsilon_{1 i}
$$


where $W_{i}^{*}$ is the net benefit attained by the family by sending the child to work, is the vector of child, parent and household characteristics, as well as regional and community dummies that determine $W_{i}^{*}$, and is the random error, with zero mean and unit variance. However, $W_{i}^{*}$ is not observed. What is observed is the following binary variable:

1 , if the child worked in the last 7 days

0 , otherwise

Correspondingly, the decision to send a child to school is described by the following latent variable model:

$S_{i}^{*}$ is the net benefit to the family from sending the child to school, is the vector of child, parent and household characteristics as well as regional and community dummies that determine $S_{i}^{*}$, and is the random error with zero mean and unit variance. Again, $S_{i}^{*}$ is not observed; what we observe is the following binary variable:

1 , if the child participated in school in the last 7 days

0 , otherwise

We can put these two equations (Equation 1 and Equation 2) into observable form, $\mathrm{Y}_{i}$.

$\mathrm{Y}_{i}=1: \quad>0$, otherwise, 0 (child involve in economic activities in the last seven days), which is called logit work

$\mathrm{Y}_{i}=1: \quad>0$, otherwise, 0 (child attends school in the last seven days), which is called logit school

\section{Logit regression results}

Table 33 presents the logit regression estimates of child's work/school choices, which are: child is involved in economic activities (work) or attends school but does not work (school). The logit school has dependent variable equal to 1 if the child is involved in schooling and 0 otherwise, while logit work has dependent variable of 1 if the child is involved in work and 0 otherwise. The child's age and gender were used to capture child characteristics. Variables used to describe household characteristics are the age, gender and main source of income of the household head; number of children in the household; number of adults in the household; and log of adult income. Parent-specific variables are the mother's presence status in the household, education of the father and mother taken separately, and the distance to school. The community variables include zones and location of the child (rural or urban). These variables and their definitions are presented in Appendix Tables B1 and B2. 
The result of logit regression analysis implies that the predictors are significant as indicated by the chi-square result. However, the pseudo $\mathrm{R}^{2}$ (which measures how the independent variable explains the variation in dependent variable) shows that the pseudo $\mathrm{R}^{2}$ for logit school is higher than those of logit work. This implies that the independent variables used better explain the variation in the probability of attending school than probability of the child working. The discussions of the analysis will be divided into child characteristics, parent characteristics, household characteristics and community characteristics.

Table 33: The logit regression results

\begin{tabular}{|c|c|c|c|c|}
\hline $\begin{array}{l}\text { Independent } \\
\text { Variables } \\
\end{array}$ & $\begin{array}{l}\text { Logit work } \\
\text { coefficients }\end{array}$ & $\begin{array}{c}\text { Logit work } \\
\text { t - values }\end{array}$ & $\begin{array}{l}\text { Logit school } \\
\text { coefficients }\end{array}$ & $\begin{array}{c}\text { Logit school } \\
\text { t - values }\end{array}$ \\
\hline $\mathrm{Ag}$ & 0.51 & $4.90^{\star \star}$ & -0.48 & $-2.98^{\star \star}$ \\
\hline $\mathrm{Ag}^{2}$ & -0.02 & $-4.21^{\star *}$ & 0.16 & $2.73^{\star \star}$ \\
\hline Sexch & -0.16 & $-2.22^{\star \star}$ & -0.11 & $-1.99^{\star \star}$ \\
\hline Fanedu & 0.98 & $2.11^{\star \star}$ & -0.75 & 0.56 \\
\hline Fapedu & -0.92 & $-2.00^{\star *}$ & 0.31 & 0.47 \\
\hline Fasedu & -0.71 & -1.51 & 0.57 & 0.97 \\
\hline Fapsedu & 0.94 & $-1.95^{\star \star}$ & -0.97 & $-1.94^{\star \star}$ \\
\hline Manedu & -1.22 & -0.72 & 1.76 & 0.98 \\
\hline Mapedu & -1.05 & -0.62 & 1.21 & 0.89 \\
\hline Masedu & -1.02 & -0.60 & 0.98 & $2.84^{\star *}$ \\
\hline Mapsedu & -1.24 & -0.71 & 1.34 & 1.24 \\
\hline Motherin & 0.02 & 0.17 & 0.00 & 0.96 \\
\hline Adpers & 0.04 & $2.57^{\star \star}$ & -0.53 & $-3.24^{\star \star}$ \\
\hline Chd & -0.05 & $-2.06^{\star \star}$ & 0.07 & 0.76 \\
\hline Hhage & 0.00 & $1.80^{*}$ & 0.00 & 0.77 \\
\hline Sex & -0.19 & -0.11 & 0.03 & 1.41 \\
\hline Farmhh & -0.22 & $-2.69^{\star \star}$ & 1.37 & $-5.79^{\star \star}$ \\
\hline Logadinc & -0.75 & $-3.09^{\star \star}$ & 0.71 & 1.55 \\
\hline Dist & 0.38 & 1.03 & -0.98 & $-2.17^{\star \star}$ \\
\hline $\mathrm{Sec}$ & & 0.24 & $2.55^{\star \star}$ & -0.47 \\
\hline $2.13^{\star \star}$ & & & & \\
\hline Zone1 & -0.37 & -0.34 & 0.02 & 1.06 \\
\hline Zone2 & 0.00 & 0.06 & -0.09 & $-3.56^{\star \star}$ \\
\hline Zone3 & 0.10 & 0.84 & -0.07 & $-2.07^{\star *}$ \\
\hline Zone5 & 0.06 & 0.51 & -0.03 & -0.99 \\
\hline Zone6 & -1.68 & $-10.20^{* *}$ & 1.89 & $6.78^{\star *}$ \\
\hline Log likelihood & \multicolumn{2}{|c|}{2421.65} & \multicolumn{2}{|c|}{3578.99} \\
\hline Pseudo $\mathrm{R}^{2}$ & \multicolumn{2}{|c|}{0.06} & \multicolumn{2}{|c|}{0.11} \\
\hline $\mathrm{Chi}^{2}$ & \multicolumn{2}{|c|}{$335.22^{* *}$} & \multicolumn{2}{|c|}{$576.23^{\star *}$} \\
\hline Number of observations & \multicolumn{2}{|c|}{4,156} & \multicolumn{2}{|c|}{4,173} \\
\hline
\end{tabular}

Note: ${ }^{* *}=$ significant at $5 \%$ probability level.

Computed from Child Labour Survey 2001. 


\section{Determinants of child work}

Variables examined here include child, parent and household characteristics.

Child characteristics. Virtually all empirical work in child labour studies has indicated that the age and gender of the child are important determinants of child schooling. The effect of age is generally significant. The positive sign of the coefficients for logit work indicates that older children are more likely than younger children to be engaged in economic activities. The negative age square coefficient for children suggests, however, that the inflow into working or participating in economic activities becomes weaker in the younger age groups. The gender coefficient is negative and positive for logit work, which suggests that males are more likely than females to participate in work activities.

Parent characteristics. According to Assad (2000), younger parents are more likely to be more resource-constrained in their life cycle, with less ability to pay school-related fees and consequently children from such a household are more likely to be in economic activities. Our result, however, shows that age of the parents has a positive and significant relationship with child participation in economic activities. This indicates that each additional increase in age increases the odds of child participation in economic activities. In simple language, the result shows that it is more likely that children from older parents will participate in economic activities than younger parents. This result is probably because older parents may have lesser opportunity of gaining employment that is needed to pull their children from economic activities. This result contradicts the study by Assaad et al. (2000).

There is ample empirical evidence that education of the parents affects the child labour decision (Patrinos and Psacharopoulos, 1995). The usual assumption is that the father's education has more impact on boys, while the mother's education affects girls the most. Although the analysis was not disaggregated by gender, the result shows that most parental characteristics used as explanatory variables generally exert no impact on child work except the father's education. Education of the father has a negative and significant relationship with the participation of the child in economic activities. Specifically, the father's primary or post-secondary school education shows a negative relationship with the participation of a child in economic activities. Education of the mother shows no statistically significant relationship with child work options in Nigeria, but it does have a negative association with the involvement of a child in economic activities, except in a situation where the mother or father has no formal education compared with those holding vocational or technical education.

These results suggest that increasing the educational status of the parents and indeed the father to primary or post-secondary school level discourages the participation of children in economic activities. Similar results have been found elsewhere (Patrinos and Psacharapoulos, 1997; Psacharopoulos, 1997).

Household characteristics. Household composition generally exerts different significant impacts on the child's economic activities through the number of adult persons in the household, age of the household head, total number of children in the household (excluding 
those used as the dependent variable), the household major source of income and the log of adult income. The result shows that the age of the household head and the number of adults in the household positively and significantly influence child participation in economic activities. The implication of this is that increasing these variables also increases the odds of the child participating in economic activities.

The result also shows that the number of children in the household and the major source of household income have a negative affect on the odds of a child participating in economic activities. A unit increase in the number of children in the household reduces the odds of a child participating in economic activities. Although the reason for this is not clear, it implies that increase in the number of children does not necessarily mean increase in expenditure for the household. The result also shows that if the major source of income of the household is irregular, such as farming, the risk of a child participating in economic activities is increased.

Household income has a negative and significant relationship with child participation in economic activities, implying that an increase in household income reduces the odds of a child participating in economic activities. This seems to confirm that poverty is an important variable in children's participation in economic activities, a conclusion that is supported in the literature (see Cartwright and Patrinos, 1999). In sum, the results confirm the result of the descriptive statistics, which revealed that children's contribution to household income ranges from $3.5 \%$ to $38 \%$.

Community dummy. The variables used in capturing community characteristics are location in terms of zone and sector (rural or urban). The result shows that location has significant influence on the child's participation in economic activities. Specifically, the location of a child by zone does not matter except in Southwest (which has negative and significant effect on participation of the child in economic activities), and in North East and North West, which have positive and significant effects on participation of the child in economic activities compared with children from the South East. The result also shows that children in rural areas are more likely to participate in economic activities. The degree of participation as indicated by the t-value shows that there is a significant difference between rural and urban children in different child activity options execpt gender differences in idling activities, which is statistically not significant.

\section{Determinants of child schooling}

The econometric model shows that child schooling is determined by child, parent, household and regional characteristics, as well as community dummies. These are discussed in turn.

Child characteristics. The result shows that age has a negative association with child schooling. This implies that younger children are more likely to attend school than older children, and the positive age squared suggests that inflow of children into school becomes weaker for older children. Gender of the child also matters in child participation in schooling activity. The result shows that males are more likely to be in school than females, supporting the greater importance attached to the education of boys. 
Parent characteristics. The result shows that children from households whose father or mother holds secondary school education are more likely to be in school than those from households whose father holds technical or vocational education.

Household characteristics. Household composition as measured by the number of adults in the household exerts a negative influence on child schooling. In addition, the occupation of the household head also matters in encouraging or discouraging child schooling. The result shows that it is more likely that children from farming households will not be in school compared with those from non-farming households. It is a surprise that although household income has a positive association with child schooling, is not statistically significant. This shows that parents are willing to put their children in school no matter how poor they are. This is supported in the literature (Basu, 1998), which says that household income has a very weak association with child participation in schooling.

Regional characteristics. The result shows that it is more likely that children in rural, North West and North East will not go to school compared with those from South East. In addition, it is more likely that children in South West will go to school compared with those from South East. This implies that the regional variable is capturing variables other than regional poverty (because poverty is controlled). These could be religion and socio-cultural factors, which unfortunately were not covered in the survey. Distance to school, which was used as a proxy for access to school, shows a negative and significant influence on child schooling. 


\section{Conclusion and policy implications}

7 he issue of child labour, which is at the heart of the development literature today, has attracted considerable attention in recent years. Although there has been significant effort to reduce this problem, child labour participation in Nigeria and indeed other developing countries is still large enough to cause serious concern. Any effective strategies aimed at addressing child labour should focus on its incidence, identifying its key determinants and disaggregating this incidence into different household poverty levels. Our broad objective was to investigate the incidence and how various factors such as individual, household and community variables influence child welfare using participation in school or in economic activities as a case variable of child welfare. A common logit model estimation framework was used to achieve the broad objective of the study.

The central message of this research is that one needs to recognize regional and sectoral diversity, along with child and household characteristics, in formulating appropriate policies for reducing the incidence of child work in Nigeria. For example, there was high incidence of exclusive child labourers and idling children in Northern Nigeria, while in Southern Nigeria there is relatively higher incidence of child enrolment in school. The study also revealed a higher percentage of children participating in economic activities in rural than urban areas. Participation is also gender sensitive, as more females participate in economic activities and fewer in schooling than male children. There is need to take this diversity into account in formulating a sustainable policy to reduce child labour in Nigeria. In terms of age, the study observed that among the child workers and those participating in neither school nor work activity, a high percentage belongs to the notenrolled category. This is about $8 \%$ of the children in the sample. The real problem lies in the 5-11 age group of children (who are potential primary school children). These children lost the benefits of schooling, implying a loss of human capital formation. In this, priority should be given to genuine national effort (such as adult literacy campaigns) to increase school enrolment in general and for girls and rural residents in particular. There should also be a concerted effort to ensure the enrolment of potential primary school pupils by providing free and compulsory primary education or, alternatively, by affording them the opportunity to acquire necessary skills training or to make up to some extent their lack of education through government policies and interventions by community-based (CBOs) and non-government organizations (NGOs).

The data revealed that although female children spent more hours in economic activities, they receive less income than male children. In addition, children from the North spent more hours in economic activities than those in Southern Nigeria, yet they 
are paid less. The data also demonstrate that the earnings of an individual are correlated with the age of entry into economic activities. Generally, the earlier children begin to work, the lower their earnings. Girls are more adversely affected than boys in this early entry into economic activities. Effort should be made to avoid differential wage on gender basis (if a child must work) to reduce the possibility of this differential in later stages of life. The wage should be based on hours spent and not on gender.

An examination of the reasons for children never being enrolled and discontinuing indicates that parental and child interest, lack of school in the vicinity, and the poverty status of the parents were the major factors. The supply side - the distance to school emerges as an important reason only for discontinuing school. The lack of interest may be because of the poor quality of schooling and envisaged low returns to education in Nigeria. Although we are unable to infer much on this, improving school structure, building more schools, and making education (at least at primary school level) free and compulsory may rekindle interest in schooling. Campaigns by government to motivate children to go to school are important. All these imply not only an expansion of government spending on education but also well targeted policies.

Children of less educated parents show a lower percentage of school attendance and higher percentage of not-enrolled category. Specifically, a higher percentage of girls than boys belong to this category. Increased provision of public enlightenment services and adult literacy programmes should be provided by the government, while communitybased and non-government organizations should increase efforts to raise awareness on the need for child education. More of these efforts should be addressed to fathers to make them understand that education of the girl-child is equally important.

The result from the study also shows that poorer households, especially in rural areas, and farming households are consistently worse off than the rich in terms of school enrolment. To this end, there is need to target poor households by providing some assistantships such as bursaries or soft loans for schooling, as well as creating opportunities for them to work or subsidizing their farming inputs as these will help alleviate their poverty status. It seems right also to say that the presence of the parents in the household is determined by economic pressure within the household. Therefore, any policy that will effectively address the minimum wage policy and unemployment in Nigeria will be a welcome development towards reducing children's participation in economic activities in Nigeria. This will help in child welfare enhancing policies.

The study established that children from larger households participate more in economic activities and less in schooling activities than children from smaller households. This seems to imply that larger households usually lack resources to send their children to school. Government and non-government organizations should enhance their campaign machinery on the importance of family planning.

In conclusion, therefore, it is obvious that most households cannot help sending their child to work, especially poor households. While the overall goal of policies must be to move the child from exclusive labouring or a no school/no work situation to "school only" status, this can only be a long-term objective. In the short run, any policy that moves a child from exclusive labourer or "neither work nor school" status to one where the child combines schooling with work must be considered a significant success. That 
must be the immediate target of stakeholders in child welfare in Nigeria. Therefore, appropriate programmes should be designed to compensate families for a child's forgone earnings and mitigate the family characteristics that lead to poverty. The targeting mechanism as well as monitoring and evaluation of programmes intended to reduce the participation of children in economic activities should explicitly consider household, regional and child characteristics, as well as community factors, in such design.

Many non-economic factors - including social and cultural norms and religious beliefs - may have potentially important effects on child schooling or work. This unfortunately was not covered in the survey. Future child labour surveys in Nigeria should consider collecting such data to ensure a well-targeted child labour reduction programme in Nigeria. 


\section{References}

Assaad, Ragui, Deborah Levison and Nadia Zibani. 2000. "The effect of child work on schooling enrolment in Egypt”. Economic Research Forum Working Paper 0111, Cairo, Egypt.

Basu, Kaushik. 1998. "Child labor: Cause, consequence, and cure, with remarks on international labor standards". Policy Research Working Paper No. 2027. The World Bank, Washington, D.C.

Basu, Kaushik and Va Pham Hoang. 1998. "The economics of child labor". American Economic Review, 88(3): 412-27.

Behrman J., R. Pollak and P. Taubman. 1999. "The wealth model: Efficiency in education and distribution in family." In J. Behrman, ed., From Parent to Child: Intrahousehold Allocation and Intergenerational Relations in the Limited State. Chicago: University of Chicago Press.

Blunch, N.H. and D. Verner. 2000. "Revisiting the link between poverty and child labour: The Ghanaian experience". Policy Research Working Paper No. 2488. The World Bank, Washington, D.C.

Bonnet, M. 1993. "Child labour in Africa". International Labour Review, 132(3): 37189.

Canagarajah, Sudharshan and Harold Coulombe. 1997. "Child labor and schooling in Ghana”. Policy Research Working Paper No. 1844. The World Bank, Washington, D.C.

Cartwright, K. and H.A. Patrinos. 1999. "Child labour in urban Bolivia”. In C. Grootaert. and H. Patrinos, eds., The Policy of Child Labour: A Comparative Study. New York: St. Martin's Press.

Federal Office of Statistics (FOS). 2001. Poverty Profile for Nigeria 1980-1996. Federal Office of Statistics, Abuja, Nigeria.

Fallon, P. and T. Zafiris. 1998. "Child labour: Issues and discussion for the World Bank Social Protection and Human Development Network". The World Bank, Washington, D.C.

Genicot, Garance. 1998. "An efficiency wage theory of child labor: Exploring the implications of some ideas of Leibenstein and Marx". Department of Economics Working Paper No. 463. Cornel University, Ithaca, New York.

Glick, P. and D. Sahn. 1997. "Gender and education impacts on employment and earnings in a developing country: The case of Guinea". Economic and Cultural Change, 45(4): 793-823. 
Grootaert, Christiaan. 1998. "Child labor in Cote d'Ivoire: Incidence and determinants". Policy Research Working Paper No. 1905. The World Bank, Washington, D.C.

Grootaert, Christiaan and Ravi Kanbur. 1995. "Child labor: An economic perspective". International Labor Review, 134(2): 187-203.

ILO. 1996. "Child labour: Targeting the intolerable". Report VI, Part 1, International Labour Conference 85th Session. Geneva: International Labour Organization.

Levison, D. 1991. "Children labour force and school attendance? Evidence from Zambia". Journal of Population Economics, 10(4): 407-24.

Lloyd, Cynthia and Ann K. Blanc. 1994. "Children schooling in Sub-Saharan African: The role of fathers, mothers, and others". Population and Development Review, 22: 265-98.

Jayaraj, D. and S. Subramanian. 1997. "Child labour in Tamilradu: A preliminary account of its nature, extent and distribution”. Working Paper No. 151. Madras Institute of Development Studies, Chennai.

Nelson, H.S. 2000. "Child labour and schooling in Zambia", World Bank Working Paper Series, No. 98.

Nielsen, H. 1998. "Child labor and school attendance: Two Joint Decisions". University of Aarhus, Denmark, CLS Working Paper Series, No. 98

Partrinos, H. and G. Psacharopoulos. 1995. "Educational performance and child labor in Paraguay". International Journal for Educational Development, 15(1): 47-60.

Patrinos, H. and G. Psacharopoulos. 1997 "Family size, schooling and child labor in Peru: An empirical analysis." Journal of Population Economics. 10: 387-405.

Psacharopoulos, G. 1997. "Child labor versus educational attainment - Some evidence from Latin America". Journal of Population Economics, 10(4):377-86.

Ravallion, M. and Q. Wodom. 2000. "Does a child's labour displace schooling? Evidence on behavioural responses to an enrolment subsidy". The Economic Journal, 110 (462): 158-75.

Ray, Ranjan. 1998. "Analysis of child labour in Peru and Pakistan: A comparative study". Mimeograph. Hobert, Australia.

Ray, Ranjan. 2000. "Analysis of child labour in Peru and Pakistan: A comparative study". Journal of Population Economics, 12: 3-19.

Rimmer, K. 1992. Staying Poor: Ghana's Political Economy, 1950-1990. Oxford: Pergamon Press for the World Bank.

Siddiqi, F. and H.A. Patrinos. 1995. "Child labor: Issues, causes and interventions". Human Resource Development and Operation Policy Working Paper Series No. 56. The World Bank, Washington, D.C.

Strauss, John, Germano Mwabu and Kathleen Beegle. 2000. "Intrahousehold allocations: A review of theories and empirical evidence". Journal of African Economies, 9(Supplement 1): 83-143.

UNICEF. 2002. The State of the World's Children 1997. Oxford: Oxford University Press. 


\section{Appendix A Test of child acting options}

Table A1: $\quad$ Testing the child activity options across gender, zone and sector

\begin{tabular}{lccccccccc} 
Variables & \multicolumn{2}{c}{ School only } & \multicolumn{2}{c}{ Work only } & School and work & \multicolumn{2}{c}{ Idling } \\
\cline { 2 - 9 } & t-cal & Probability & t-cal & Probability & t-cal & Probability & t-cal & Probability \\
& & & & & & & & & \\
Male versus female & $3.90^{*}$ & 0.0001 & $7.76^{*}$ & 0.0000 & $5.47^{*}$ & 0.0000 & -0.15 & 0.88 \\
North versus South & $-57.04^{*}$ & 0.0000 & $22.69^{*}$ & 0.0000 & 2.28 & 0.0227 & $26.48^{*}$ & 0.000 \\
Urban versus rural & $28.17^{*}$ & 0.0000 & $-10.72^{*}$ & 0.0000 & $-5.15^{*}$ & 0.0000 & $-10.88^{*}$ & 0.0000 \\
\hline
\end{tabular}




\section{Appendix B Explanation of variable}

Appendix B: Definition of variables used in logit regression

Dependent variable

Logit work $\quad=$ if is involved in any economic activity in the last 7 days; 0 otherwise

Logit school $=$ if went to school in the last 7 days; 0 otherwise

Child characteristics

$\mathrm{Ag} \quad=$ age of the child in years

Ag2 = square of the child's age

Sexch $\quad=1$ if male; 0 otherwise

Parent characteristics

Fanedu $\quad=1$ if father had no formal education; 0 otherwise

Fapedu $\quad=1$ if father had primary education; 0 otherwise

Fasedu $\quad=1$ if father secondary education; 0 otherwise

Fapsedu $\quad=1$ if father had post secondary education; 0 otherwise

Manedu $\quad=1$ if mother had no formal education; 0 otherwise

Mapedu $\quad=1$ if mother had primary education; 0 otherwise

Masedu $\quad=1$ if mother had secondary education 0 otherwise

Mapsedu $\quad=1$ if mother had post-secondary education; 0 otherwise

Household characteristics

Motherin $\quad=1$ if mother present in the household; 0 otherwise

adpers $\quad=$ total number of persons aged above 55 years in the household

Chd $\quad=$ total number of children in the household

hhage $\quad=$ age of the household head

sex $\quad=1$ if sex of the household head is male; 0 otherwise

Farminhh $\quad=1$ if household major source of income is farming; 0 otherwise

Logadinc $=$ log of adult income

Table B2: Definition of community variables used in logit regression

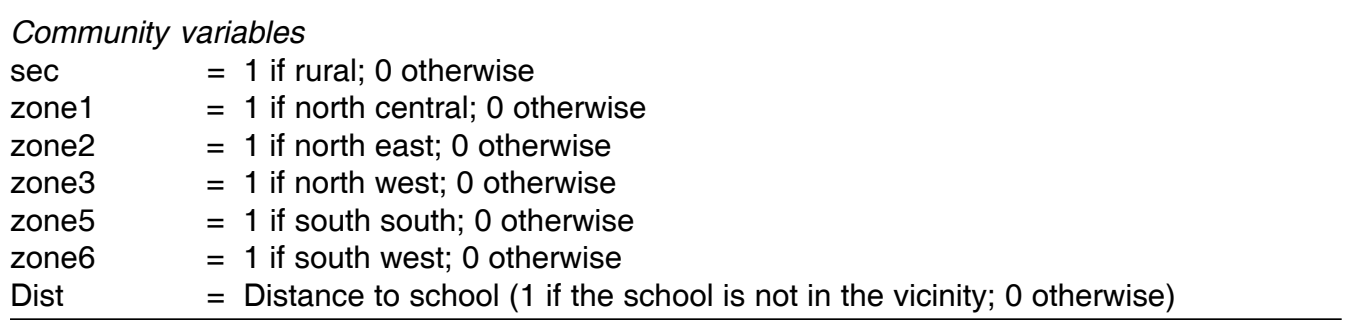

Note: technical and vocational education were used for comparison.

Zone 4 was used for comparison. 


\section{Other recent publications in the AERC Research Papers Series:}

The Behaviour of Income Velocity in Tanzania 1967-1994, by Michael O.A. Ndanshau, Research Paper 50.

Consequences and Limitations of Recent Fiscal Policy in Côte d'Ivoire, by Kouassy Oussou and Bohoun Bouabre, Research Paper 51.

Effects of Inflation on Ivorian Fiscal Variables: An Econometric Investigation, by Eugene Kouassi, Research Paper 52.

European Economic Integration and the Franc Zone: The Future of the CFA Franc after 1999, Part II, by Allechi M'Bet and Niamkey A. Madeleine, Research Paper 53.

Exchange Rate Policy and Economic Reform in Ethiopia, by Asmerom Kidane, Research Paper 54.

The Nigerian Foreign Exchange Market: Possibilities for Convergence in Exchange Rates, by P. Kassey Garba, Research Paper 55.

Mobilizing Domestic Resources for Economic Development in Nigeria: The Role of the Capital Market, by Fidelis O. Ogwumike and Davidson A. Omole, Research Paper 56.

Policy Modelling in Agriculture: Testing the Response of Agriculture to Adjustment Policies in Nigeria, by Mike Kwanashie, Abdul-Ganiyu Garba and Isaac Ajilima, Research Paper 57.

Price and Exchange Rate Dynamics in Kenya: An Empirical Investigation (1970-1993), by Njuguna S. Ndung'u, Research Paper 58.

Exchange Rate Policy and Inflation: The Case of Uganda, by Barbara Mbire, Research Paper 59.

Institutional, Traditional and Asset Pricing Characteristics of African Emerging Capital Markets, by Ino L. Inanga and Chidozie Emenuga, Research Paper 60.

Foreign Aid and Economic Performance in Tanzania, by Timothy S. Nyoni, Research Paper 61.

Public Spending, Taxation and Deficits: What Is the Tanzanian Evidence? by Nehemiah Osoro, Research Paper 62.

Adjustment Programmes and Agricultural Incentives in Sudan: A Comparative Study, by Nasredin A. Hag Elamin and Elsheikh M. El Mak, Research Paper 63.

Intra-industry Trade between Members of the PTA/COMESA Regional Trading Arrangement, by Flora Mndeme Musonda, Research Paper 64.

Fiscal Operations, Money Supply and Inflation in Tanzania, by A.A.L. Kilindo, Research Paper 65.

Growth and Foreign Debt: The Ugandan Experience, by Barbara Mbire, Research Paper 66.

Productivity of the Nigerian Tax System: 1970-1990, by Ademola Ariyo, Research Paper 67.

Potentials for Diversifying Nigeria's Non-Oil Exports to Non-Traditional Markets, by A. Osuntogun, C.C. Edordu and B.O. Oramah, Research Paper 68.

Empirical Studies of Nigeria's Foreign Exchange Parallel Market II: Speculative Efficiency and Noisy Trading, by Melvin Ayogu, Research Paper 69.

Effects of Budget Deficits on the Current Account Balance in Nigeria: A Simulation Exercise, by Festus O. Egwaikhide, Research Paper 70.

Bank Performance and Supervision in Nigeria: Analysing the Transition to a Deregulated Economy, by O.O. Sobodu and P.O. Akiode, Research Paper 71.

Financial Sector Reforms and Interest Rate Liberalization: The Kenya Experience, by R.W. Ngugi and J.W. Kabubo, Research Paper 72.

Local Government Fiscal Operations in Nigeria, by Akpan H. Ekpo and John E.U. Ndebbio, Research Paper 73.

Tax Reform and Revenue Productivity in Ghana, by Newman Kwadwo Kusi, Research Paper 74.

Fiscal and Monetary Burden of Tanzania's Corporate Bodies: The Case of Public Enterprises, by H.P.B. Moshi, Research Paper 75.

Analysis of Factors Affecting the Development of an Emerging Capital Market: The Case of the Ghana Stock Market, by Kofi A. Osei, Research Paper 76.

Ghana: Monetary Targeting and Economic Development, by Cletus K. Dordunoo and Alex Donkor, Research Paper 77.

The Nigerian Economy: Response of Agriculture to Adjustment Policies, by Mike Kwanashie, Isaac Ajilima and Abdul-Ganiyu Garba, Research Paper 78.

Agricultural Credit under Economic Liberalization and Islamization in Sudan, by Adam B. Elhiraika and Sayed A. Ahmed, Research Paper 79. 
Study of Data Collection Procedures, by Ademola Ariyo and Adebisi Adeniran, Research Paper 80.

Tax Reform and Tax Yield in Malawi, by C. Chipeta, Research Paper 81.

Real Exchange Rate Movements and Export Growth: Nigeria, 1960-1990, by Oluremi Ogun, Research Paper 82.

Macroeconomic Implications of Demographic Changes in Kenya, by Gabriel N. Kirori and Jamshed Ali, Research Paper 83.

An Empirical Evaluation of Trade Potential in the Economic Community of West African States, by E. Olawale Ogunkola, Research Paper 84.

Cameroon's Fiscal Policy and Economic Growth, by Aloysius Ajab Amin, Research Paper 85.

Economic Liberalization and Privatization of Agricultural Marketing and Input Supply in Tanzania: A Case Study of Cashewnuts, by Ngila Mwase, Research Paper 86.

Price, Exchange Rate Volatility and Nigeria's Agricultural Trade Flows: A Dynamic Analysis, by A.A. Adubi and F. Okunmadewa, Research Paper 87.

The Impact of Interest Rate Liberalization on the Corporate Financing Strategies of Quoted Companies in Nigeria, by Davidson A. Omole and Gabriel O. Falokun, Research Paper 88.

The Impact of Government Policy on Macroeconomic Variables, by H.P.B. Moshi and A.A.L. Kilindo, Research Paper 89.

External Debt and Economic Growth in Sub-Saharan African Countries: An Econometric Study, by Milton A. Iyoha, Research Paper 90.

Determinants of Imports in Nigeria: A Dynamic Specification, by Festus O. Egwaikhide, Research Paper 91.

Macroeconomic Effects of VAT in Nigeria: A Computable General Equilibrium Analysis, by D. Olu Ajakaiye, Research Paper 92.

Exchange Rate Policy and Price Determination in Botswana, by Jacob K. Atta, Keith R. Jefferis, Ita Mannathoko and Pelani Siwawa-Ndai, Research Paper 93.

Monetary and Exchange Rate Policy in Kenya, by Njuguna S. Ndung'u, Research Paper 94.

Health Seeking Behaviour in the Reform Process for Rural Households: The Case of Mwea Division, Kirinyaga District, Kenya, by Rose Ngugi, Research Paper 95.

Trade and Exchange Policy Options for the CFA Countries: Simulations with a CGE MOdel for Cameroon, by Dominique Njinkeu and Ernest Bamou, Research Paper 96.

Trade Liberalization and Economic Performance of Cameroon and Gabon, by Ernest Bamou, Research Paper 97.

Quality Jobs or Mass Employment, by Kwabia Boateng, Research Paper 98.

Real Exchange Rate Price and Agricultural Supply Response in Ethiopia: The Case of Perennial Crops, by Asmerom Kidane, Research Paper 99.

Determinants of Private Investment Behaviour in Ghana, by Yaw Asante, Research Paper 100.

An Analysis of the Implementation and Stability of Nigerian Agricultural Policies, 1970-1993, by P. Kassey Garba, Research Paper 101.

Poverty, Growth and Inequality in Nigeria: A Case Study, by Ben E. Aigbokhan, Research Paper 102.

Effect of Export Earnings Fluctuations on Capital Formation, by Godwin Akpokodje, Research Paper 103.

Nigeria: Towards an Optimal Macroeconomic Management of Public Capital, by Melvin D. Ayogu, Research Paper 104.

International Stock Market Linkages in South Africa, by K.R. Jefferis, C.C. Okeahalam and T.T. Matome, Research Paper 105.

An Empirical Analysis of Interest Rate Spread in Kenya, by Rose W. Ngugi, Research Paper 106.

The Parallel Foreign Exchange Market and Macroeconomic Perfromance in Ethiopia, by Derrese Degefa, Reseach Paper 107.

Market Structure, Liberalization and Performance in the Malawi Banking Industry, by Ephraim W. Chirwa, Research Paper 108.

Liberalization of the Foreign Exchange Market in Kenya and the Short-Term Capital Flows Problem, by Njuguna S. Ndung'u, Research Paper 109.

External Aid Inflows and the Real Exchange Rate in Ghana, by Harry A. Sackey, Research Paper 110.

Formal and Informal Intitutions' Lending Policies and Access to Credit by Small-Scale Enterprises in Kenya: An Empirical Assessment, by Rosemary Atieno, Research Paper 111. 
Financial Sector Reform, Macroeconomic Instability and the Order of Economic Liberalization: The Evidence from Nigeria, by Sylvanus I. Ikhinda and Abayomi A. Alawode, Research Paper 112.

The Second Economy and Tax Yield in Malawi, by C. Chipeta, Research Paper 113.

Promoting Export Diversification in Cameroon: Toward Which Products? by Lydie T. Bamou, Research Paper 114.

Asset Pricing and Information Efficiency of the Ghana Stock Market, by Kofi A. Osei, Research Paper 115.

An Examination of the Sources of Economic Growth in Cameroon, by Aloysius Ajab Amin, Research Paper 116.

Trade Liberalization and Technology Acquisition in the Manufacturing Sector: Evidence from Nigeria, by Ayonrinde Folasade, Research Paper 117.

Total Factor Productivity in Kenya: The Links with Trade Policy, by Joseph Onjala, Research Paper 118.

Kenya Airways: A Case Study of Privatization, by Samuel Oyieke, Research Paper 119.

Determinants of Agricultural Exports: The Case of Cameroon, by Daniel Gbetnkon and Sunday A. Khan, Research Paper 120.

Macroeconomic Modelling and Economic Policy Making: A Survey of Experiences in Africa, by Charles Soludo, Research Paper 121.

Determinants of Regional Poverty in Uganda, by Francis Okurut, Jonathan Odwee and Asaf Adebua, Research Paper 122.

Exchange Rate Policy and the Parallel Market for Foreign Currency in Burundi, by Janvier D. Nkurunziza, Research Paper 123.

Structural Adjustment, Poverty and Economic Growth: An Analysis for Kenya, by Jane KabuboMariara and Tabitha W. Kiriti, Research Paper 124.

Liberalization and Implicit Government Finances in Sierra Leone, by Victor A.B. Davis, Research Paper 125.

Productivity, Market Structure and Trade Liberalization in Nigeria, by Adeola F. Adenikinju and Louis N. Chete, Research Paper 126.

Productivity Growth in Nigerian Manufacturing and Its Correlation to Trade Policy Regimes/Indexes (1962-1985), by Louis N. Chete and Adeola F. Adenikinju, Research Paper 127.

Financial Liberalization and Its Implications for the Domestic Financial System: The Case of Uganda, by Louis A. Kasekende and Michael Atingi-Ego, Research Paper 128.

Public Enterprise Reform in Nigeria: Evidence from the Telecommunications Industry, by Afeikhena Jerome, Research Paper 129.

Food Security and Child Nutrition Status among Urban Poor Households in Uganda: Implications for Poverty Alleviation, by Sarah Nakabo-Sswanyana, Research Paper 130.

Tax Reforms and Revenue Mobilization in Kenya, by Moses Kinyanjui Muriithi and Eliud Dismas Moyi, Research Paper 131.

Wage Determination and the Gender Wage Gap in Kenya: Any Evidence of Gender Discrimination? by Jane Kabubo-Mariara, Research Paper 132.

Trade Reform and Efficiency in Cameroon's Manufacturing Industries, by Ousmanou Njikam, Research Paper 133.

Efficiency of Microenterprises in the Nigerian Economy, by Igbekele A. Ajibefun and Adebiyi G. Daramola, Research Paper 134.

The Impact of Foreign Aid on Public Expenditure: The Case of Kenya, by James Njeru, Research Paper 135.

The Effects of Trade Liberalization on Productive Efficiency: Electrical Industry in Cameroon, by Ousmanou Njikam, Research Paper 136.

How Tied Aid Affects the Cost of Aid-Funded Projects in Ghana, by Barfour Osei, Research Paper 137.

Exchange Rate Regimes and Inflation in Tanzania, by Longinus Rutasitara, Research Paper 138.

Private Returns to Higher Education in Nigeria, by O.B.Okuwa, Research Paper 139.

Uganda's Equilibrium Real Exchange Rate and Its Implications for Non-Traditional Export Performance, by Michael Atingi-Ego and Rachel Kaggwa Sebudde, Research Paper 140.

Dynamic Inter-Links among the Exchange Rate, Price Level and Terms of Trade in a Managed Floating Exchange Rate System: The Case of Ghana, by Vijay K. Bhasin, Research Paper 141. 
Financial Deepening, Economic Growth and Development: Evidence from Selected Sub-Saharan African Countries, by John E. Udo Ndebbio, Research Paper 142.

The Determinants of Inflation in South Africa: An Econometric Analysis, by Oludele A. Akinboade, Franz K. Siebrits and Elizabeth W. Niedermeier, Research Paper 143.

The Cost of Aid Tying to Ghana, by Barfour Osei, Research Paper 144.

A Positive and Normative Analysis of Bank Supervision in Nigeria, by A. Soyibo, S.O. Alashi and M.K. Ahmad, Research Paper 145.

The Determinants of the Real Exchange Rate in Zambia, by Kombe O. Mungule, Research Paper 146.

An Evaluation of the Viability of a Single Monetary Zone in ECOWAS, by Olawale Ogunkola, Research Paper 147.

Analysis of the Cost of Infrastructure failures in a Developing Economy: The Case of Electricity Sector in Nigeria, by Adeola Adenikinju, Research Paper 148.

Corporate Governance Mechanisms and Firm Financial Performance in Nigeria, by Ahmadu Sanda, Aminu S. Mikailu and Tukur Garba, Research Paper 149.

Female Labour Force Participation in Ghana: The Effects of Education, by Harry A. Sackey, Research Paper 150.

The Integration of Nigeria's Rural and Urban Foodstuffs Market, by Rosemary Okoh and P.C. Egbon, Research Paper 151.

Determinants of Technical Efficiency Differentials amongst Small-and Medium-Scale Farmers in Uganda: A Case of Tobacco Growers, by Marios Obwona, Research Paper 152.

Land Conservation in Kenya: The Role of Property Rights, by Jane Kabubo-Mariara, Research Paper 153.

Technical Efficiency Differentials in Rice Production Technologies in Nigeria, by Olorunfemi Ogundele, and Victor Okoruwa, Research Paper 154.

The Determinants of Health Care Demand in Uganda: The Case Study of Lira District, Northern Uganda, by Jonathan Odwee, Francis Okurut and Asaf Adebua, Research Paper 155. 